\title{
Relationships between Ambient Ozone Concentration Changes in Southwestern Taiwan and Invasion Tracks of Tropical Typhoons
}

\author{
Chung-Hsuang Hung ${ }^{1}$ and Kuo-Cheng Lo ${ }^{1,2}$ \\ ${ }^{1}$ Department of Safety, Health, and Environmental Engineering, National Kaohsiung First University of Science and Technology, \\ Kaohsiung 811, Taiwan \\ ${ }^{2}$ Department of Military Meteorology, Air Force Institute of Technology, Kaohsiung 820, Taiwan \\ Correspondence should be addressed to Chung-Hsuang Hung; jeremyh@nkfust.edu.tw
}

Received 22 April 2015; Revised 11 June 2015; Accepted 22 June 2015

Academic Editor: Harry D. Kambezidis

Copyright (C) 2015 C.-H. Hung and K.-C. Lo. This is an open access article distributed under the Creative Commons Attribution License, which permits unrestricted use, distribution, and reproduction in any medium, provided the original work is properly cited.

\begin{abstract}
This study aimed to use a newly developed weather and air quality model, WRF-Chem, to simulate and analyze formation of high-concentrated ozone $\left(\mathrm{O}_{3}\right)$ in the ambient air of southwestern Taiwan before the invasion of tropical typhoons. Two typical typhoons, Nanmadol and Usagi that occurred in 2011 and 2013, respectively, were simulated in this study. The $\mathrm{O}_{3}$ concentration variation patterns in the ambient air of both offshore and inland parts of southwestern Taiwan were collected and analyzed. The results indicated that the high $\mathrm{O}_{3}$ concentration observed in southwestern Taiwan before typhoon arrived was mainly caused by the western Pacific subtropical high (WPSH) shrouding it. On the other hand, the latter increase in ambient $\mathrm{O}_{3}$ concentration about 1 to 2 days before issuing sea warning was mainly due to both contributions of weakening WPSH and intensifying leeward side effects. For both cases, atmospheric subsidence occurred to result in low ambient air quality. The invasion of typhoons made ambient $\mathrm{O}_{3}$ concentration enhanced up to 2-3-fold compared to its normal concentration in summer. Based on the simulated $\mathrm{O}_{3}$ concentration variation results in this study, it is demonstrated that the space-fading patterns of $\mathrm{O}_{3}$ before typhoon arrives also can be used as references for predicting typhoon moving tracks 1.0 to 2.0 days before landfall of typhoons.
\end{abstract}

\section{Introduction}

The deterioration in ambient air quality that resulted from global climate changes has attracted more and more attention [1-3]. Global warming effect not only contributes to increasing seawater temperature in the western Pacific Ocean in recent years, but also causes increases in both frequencies and intensity of typhoons generated within this area [4]. According to the study by the research group of Kossin [5], more than 50\% increase in the life cycles and intensity of typhoons was observed in the western Pacific Ocean over the past three decades (Table 1), which was consistent with temperature increases in global atmosphere and seawater. So, other than paying attention to global warming effects, it is also required to concern ambient air quality changes due to increasing number and unpredictability of typhoons [6].
Southern Taiwan usually has higher air quality in summer than the rest of the year, but the typhoon invasion is high in summer as well. Based on recent investigations, increasing cases of forming low ambient air quality are observed in Southern Taiwan before typhoon invasion [7], but its formation reason was not clear. The relationships between ambient air quality changes and typhoon invading tracks required more investigation. In fact, the moving tracks of typhoons in the western Pacific Ocean are significantly determined by the position of western Pacific subtropical high (WPSH). WPSH may stretch down to latitude as low as middle Taiwan during summer periods $[8,9]$. Therefore, when the WPSH moves away from Taiwan, the typhoons that were generated in the western Pacific Ocean would be guided to move toward Southern Taiwan by following the direction from east-southerly to west-northerly. These typhoons usually pass 
TABle 1: Frequency of typhoon formation in the western Pacific Ocean and typhoon invasions in Taiwan from 1994 to 2014.

\begin{tabular}{|c|c|c|c|c|c|}
\hline Year & $\begin{array}{l}\text { Number of typhoons } \\
\text { formed in western } \\
\text { Pacific Ocean }\end{array}$ & $\begin{array}{c}\text { Number and frequency } \\
\text { of typhoons invading } \\
\text { Taiwan }\end{array}$ & $\begin{array}{l}\text { Global average } \\
\text { temperature }\end{array}$ & $\begin{array}{c}\text { Average } \\
\text { temperature for } \\
\text { Taiwan }\end{array}$ & $\begin{array}{c}\text { East Asia ocean } \\
\text { temperature }\end{array}$ \\
\hline 1994 & 27 & $6(22 \%)$ & +0.28 & $23.47(+0.47)$ & +0.27 \\
\hline 1995 & 25 & $4(16 \%)$ & +0.34 & $23.52(+0.52)$ & +0.32 \\
\hline 1996 & 30 & $3(10 \%)$ & +0.35 & $23.49(+0.49)$ & +0.23 \\
\hline 1997 & 31 & $2(6 \%)$ & +0.47 & $23.55(+0.55)$ & +0.43 \\
\hline 1998 & 17 & $5(29 \%)$ & +0.56 & $23.60(+0.60)$ & +0.48 \\
\hline 1999 & 23 & $2(9 \%)$ & +0.39 & $23.70(+0.70)$ & +0.25 \\
\hline 2000 & 23 & $5(22 \%)$ & +0.36 & $23.80(+0.80)$ & +0.30 \\
\hline 2001 & 26 & $8(31 \%)$ & +0.49 & $23.80(+0.80)$ & +0.41 \\
\hline 2002 & 26 & $2(8 \%)$ & +0.56 & $24.20(+1.20)$ & +0.44 \\
\hline 2003 & 21 & $3(14 \%)$ & +0.56 & $23.90(+0.90)$ & +0.51 \\
\hline 2004 & 29 & $5(17 \%)$ & +0.53 & $23.60(+0.60)$ & +0.52 \\
\hline 2005 & 23 & $3(13 \%)$ & +0.61 & $23.60(+0.60)$ & +0.53 \\
\hline 2006 & 23 & $4(17 \%)$ & +0.54 & $24.20(+1.20)$ & +0.47 \\
\hline 2007 & 24 & $5(21 \%)$ & +0.55 & $24.10(+1.10)$ & +0.41 \\
\hline 2008 & 22 & $4(18 \%)$ & +0.49 & $23.80(+0.80)$ & +0.39 \\
\hline 2009 & 22 & $3(14 \%)$ & +0.60 & $23.99(+0.99)$ & +0.48 \\
\hline 2010 & 14 & $3(21 \%)$ & +0.66 & $23.87(+0.87)$ & +0.50 \\
\hline 2011 & 21 & $1(5 \%)$ & +0.53 & $23.30(+0.30)$ & +0.45 \\
\hline 2012 & 25 & $4(16 \%)$ & +0.57 & $23.71(+0.71)$ & +0.51 \\
\hline 2013 & 31 & $5(16 \%)$ & +0.62 & $23.91(+0.91)$ & +0.53 \\
\hline 2014 & 23 & $2(9 \%)$ & +0.69 & $23.95(+0.95)$ & +0.57 \\
\hline Average & 24.42 & $3.8(16 \%)$ & $13.9 \mathrm{C}^{*}$ & $23.0 \mathrm{C}^{*}$ & $16.1 \mathrm{C}^{*}$ \\
\hline
\end{tabular}

p.s.: ${ }^{*}$ the average temperature from 1901 to 2000 (ftp://ftp.ncdc.noaa.gov/pub/data/anomalies).

through the region from middle Taiwan to the Philippines. As shown in Figure 1, the Taiwan Central Weather Bureau (CWB) has concluded two major moving tracks, namely, as the fourth and fifth pathways, for these kinds of typhoons. They may directly invade Southern Taiwan from its eastsouth corner or pass through Taiwan with the Bashi Channel. However, it is usually unable to precisely predict their moving tracks when they approach this region, because of complex geological characteristics, particularly due to high mountains in Taiwan. It would be much helpful to conduct damage prevention plans if the moving tracks of typhoons can be predicted more precisely.

This study focused on air quality changes in the ambient air of offshore and inland parts of Southern Taiwan in summer while typhoons were approaching. Ozone $\left(\mathrm{O}_{3}\right)$, one of the most concerned air pollutants found in the ambient air of Southern Taiwan, was selected as a target air pollutant for analysis. It is because that long period of exposure of highconcentrated $\mathrm{O}_{3}$ can cause adverse effects on human health, including cough, chest pain, throat irritation, and congestion. $\mathrm{O}_{3}$ can also exacerbate bronchitis, emphysema, and asthma and reduce lung function and inflame the linings of the lungs [10-12]. Even at a low concentration, repeated exposure to $\mathrm{O}_{3}$ may permanently scar lung tissue. In fact, many cases of high-concentrated $\mathrm{O}_{3}$ have been observed in the ambient air of Southern Taiwan before typhoon invasions [13, 14].
According to the observations by the Taiwan Environmental Protection Administration, $\mathrm{O}_{3}$ concentration would rapidly increase in the ambient air of Southern Taiwan while typhoons were approximately 1,000 2,000 km from Taiwan, which was about 1 2 days before issuing sea warnings for typhoons. Poor dispersion of air pollutants in the atmosphere has been proposed as an important reason for forming air quality, but more precisely intrinsic mechanisms were not clarified. This study tried to use simulation results by WRFChem model to clarify the mechanism.

Ambient air pollutant concentrations are determined by several factors including emission and transformation/transportation of air pollutants in the atmosphere. Both numerical metrological simulation and air quality modeling are two commonly used tools for analyzing formation mechanisms of air pollutants in the ambient air, if both of them can corporate smoothly [15-20]. Recently, a newly proposed weather forecasting and air quality model system, the weather research and forecasting model with chemical reactions (WRF-Chem), has been demonstrated to effectively simulate and analyze reactive air pollutant concentrations in the ambient air [21-26]. WRF-Chem, which provides environments for conveniently and accurately calculating both air stream flows and air pollutant concentrations [27, 28], was developed by the U.S. government and some academic groups. 

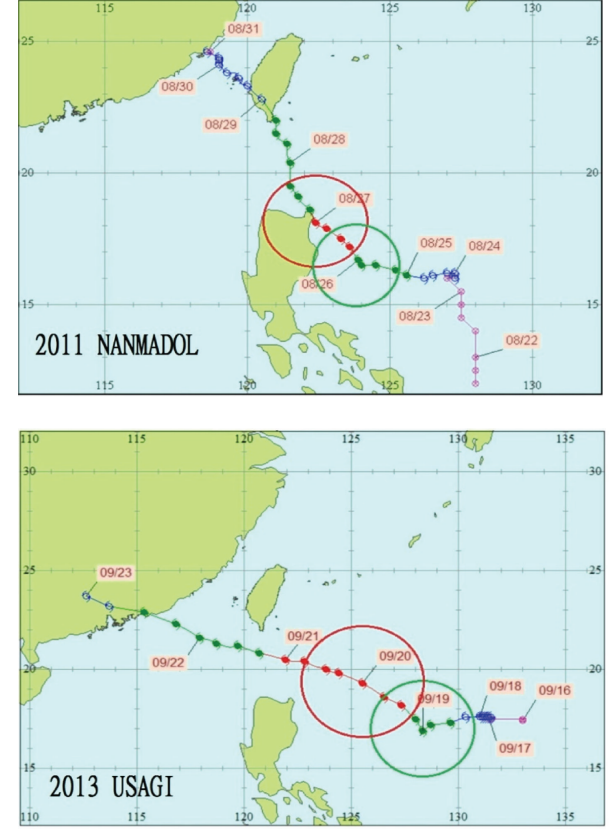

- Severe typhoon $\left(V_{\max } \geq 51.0 \mathrm{~m} / \mathrm{s}\right)$
'Tropical storm $\left(V_{\max } 17.2-36.2 \mathrm{~m} / \mathrm{s}\right)$
Typhoon $\left(V_{\max } 32.7-50.9 \mathrm{~m} / \mathrm{s}\right)$
Tropical depression $\left(V_{\max }<17.2 \mathrm{~m} / \mathrm{s}\right)$

FIGURE 1: Charts for tracking the movement of typhoons Nanmadol and Usagi (data from Taiwan CWB).

Accordingly, this study aims to explore the relationships between tropical typhoon moving tracks and ambient air quality in Southern Taiwan, where approaching typhoons usually result in low air quality before their arrival. In the study, two typical typhoon invading cases, Nanmadol (August 24 30, 2011) and Usagi (September 16 22, 2013), were simulated and analyzed by the WRF-Chem model. An analysis was conducted by focusing on $\mathrm{O}_{3}$ concentration variations before both typhoons arrive. The formation mechanisms of high-concentration $\mathrm{O}_{3}$ in the ambient air were discussed. The results obtained in this study can be used to interpret intrinsic mechanisms for causing high ozone concentrations before arrival of typhoons. Besides, the fading patterns of $\mathrm{O}_{3}$ concentration are expected to serve as references for predicting the invading tracks of typhoons.

\section{Material and Methods}

2.1. WRF-Chem Model Operation and Domain Setting. In this study, a newly proposed weather research and forecasting model involving chemistry reactions (WRF-Chem, V3.1) was used to simulate $\mathrm{O}_{3}$ concentrations in the ambient air of Southern Taiwan. By improving nonhydrostatic air flow calculation with providing various choices for physical parameterizations, WRF produces more friendly environments for massively parallel computation than previous related models $[24,27]$. WRF-Chem can use the information including emission, transport, mixing, and chemical transformation of air pollutants and wind-fields from WRF modeling for simulating reactive air pollutant concentrations in the ambient air.

For modeling the $\mathrm{O}_{3}$ concentration before the invasion of both typhoons Nanmadol and Usagi in this study, the WRFChem model was conducted from 00:00 CST of August 24 to 23:00 CST of August 30, 2011, and from 00:00 CST of September 16 to 23:00 CST of September 22, 2013, respectively. Their beginning 48 -hour periods were used as preintegration stages. Four nesting domains defined by Lambert projection, as shown and summarized in Figure 2 and Table 2, were used for the model operation. Its outermost domain (D1) has a horizontal grid of $115 \times 91$ and a grid spacing of $27 \mathrm{~km}$. D1 covers far-eastern Asia with a domain center point at $25^{\circ} \mathrm{N}$, $125^{\circ} \mathrm{E}$. Domain 2 (D2) covers the area of southern China including Taiwan. D2 has a center point at $16^{\circ} \mathrm{N}, 121^{\circ} \mathrm{E}$ and has a horizontal grid of $73 \times 73$ and a grid spacing of $9 \mathrm{~km}$. Domain 3 (D3) is designed to cover both Kaohsiung and Pingtung County located in Southern Taiwan. Its center point is at $14.5^{\circ} \mathrm{N}, 120.25^{\circ} \mathrm{E}$ and has a horizontal grid of $67 \times 58$ and a grid spacing of $1 \mathrm{~km}$. In addition, domain 4 (D4) is particularly designed to cover Magong $\left(23.34^{\circ} \mathrm{N}, 120.33^{\circ} \mathrm{E}\right)$ for model operation. Magong is a small island located in Taiwan Strait. D4 has a horizontal grid of $41 \times 41$ and a grid spacing of $1 \mathrm{~km}$. The air quality of Magong works as a reference air quality because it is not affected by high hills. Additionally, for the vertical scale, there are 28 vertical sigma layers to all grid meshes from tile ground level to the top pressure of $100 \mathrm{hpa}$. The initial meteorological fields and boundary conditions came from operational global analysis data issued by NCEP FNL with $10 \times 10$ resolution degree grids.

2.2. Air Pollutant Emission Inventories and Air Quality Data. This study investigated the ambient air quality of Southern Taiwan involving both Kaohsiung City and Pingtung County. In fact, Kaohsiung metropolitan has the largest population in Southern Taiwan, but it also has the largest heavy industrial activities in Taiwan. For $\mathrm{O}_{3}$ concentration modeling, the air pollutant emission inventory data, referred to as TEDS V7.1 issued by national emission inventories of the Taiwan Emission Data System, was used. This inventory included all of the potential pollution sources in Taiwan, which included fixed, mobile, point, face, line, and natural sources [27, 29]. Hourly $\mathrm{O}_{3}$ concentrations reported by the air quality monitoring stations located in Southern Taiwan were used to verify the simulated results.

As shown in Figure 2, Taiwan Environmental Protection Agency (EPA) has established many air quality monitoring stations in West-Southern Taiwan. They include one background ambient air quality station in Qiaotou (B-1), one industry ambient air quality station in Qianzhen (O-3), two traffic air quality stations in Fengshan (B-4) and Fuxing (B-6), and eight general ambient air quality stations in Meinong (M1), Nanzi (B-2), Renwu (B-3), Zuoying (O-1), Qianjin (O-2), Xiaogang (O-4), Dailao (B-5), and Linyuan (O-5). Besides, the Pingtung monitoring station (M-2) and the Chaozhou (M-3) monitoring station are located near Kaohsiung City [29]. Among these air quality monitoring stations, the M-1 station, approximately $300 \sim 600 \mathrm{~m}$ above sea level, is situated in the northeast side of Kaohsiung City and faces Meinong 
TABLE 2: Selected domain setting and configuration parameters for WRF-Chem model operation.

\begin{tabular}{|c|c|c|c|c|}
\hline Type of setting & D1 & $\mathrm{D} 2$ & D3 & D4 \\
\hline Horizontal grid $(x, y)$ & 115,91 & 73,73 & 67,58 & 41,41 \\
\hline Grid spacing $(\mathrm{km})$ & 27 & 9 & 1 & 1 \\
\hline Meteorological time step (sec) & 180 & 60 & 20 & 20 \\
\hline Chemical time step (sec) & 180 & 60 & 60 & 60 \\
\hline Chemistry option & \multicolumn{4}{|c|}{ RADM2 mechanism, no aerosol $[24,27]$} \\
\hline Dry deposition & \multicolumn{4}{|c|}{ Wesley, 1989} \\
\hline Photolysis option & \multicolumn{4}{|c|}{ Madronich, 1987 [17] } \\
\hline Microphysics & \multicolumn{4}{|c|}{ WSM3-class simple ice scheme } \\
\hline Cumulus physics option & \multicolumn{4}{|c|}{ Grell-Devenyi (domains D1 and D2), none for D3, D4 } \\
\hline Long wave radiation & \multicolumn{4}{|c|}{ RRTM scheme } \\
\hline Short wave radiation & \multicolumn{4}{|c|}{ GODDART scheme } \\
\hline Subgrid convective transport & \multicolumn{4}{|c|}{ Turned on } \\
\hline Photolysis option & \multicolumn{4}{|c|}{ Madronich photolysis } \\
\hline
\end{tabular}

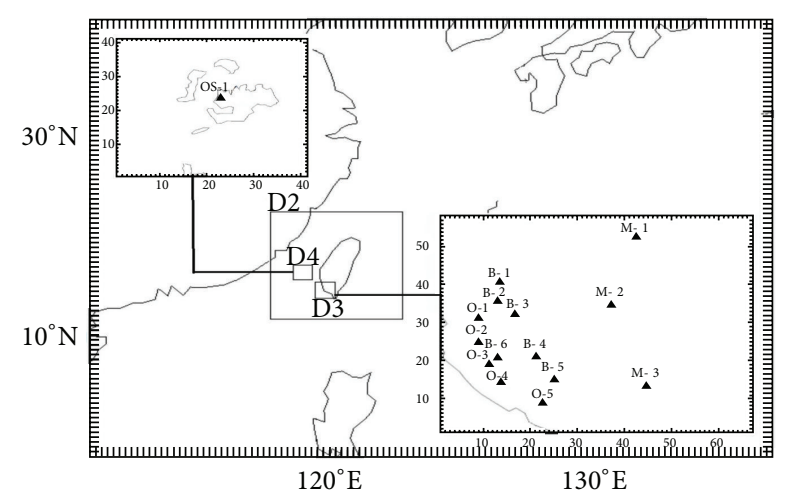

FIGURE 2: Selected nesting domain setting for WRF-Chem model operation.

Mountain that belongs to the southern extension of the Yushan Mountain range.

As shown in Table 3, the above-mentioned air quality monitoring stations were divided into four groups based on their locations, because not only can sea-land breeze effects usually affect the regions within a $10 \sim 20 \mathrm{~km}$ distance from the ocean $[28,30]$, but also leeward side effects will be more obvious while strong breeze blows toward the other side of high mountains. The air quality monitoring stations located west of $120.24^{\circ} \mathrm{E}$, including O-1 O-5, were classified as the "ocean group" stations. Monitoring stations located east of $120.30^{\circ} \mathrm{E}$, including $\mathrm{M}-1 \sim \mathrm{M}-3$, were classified as the "mountain group" stations because they are near the major mountains located at east side of Southern Taiwan. The height of these mountains can reach as high as $3000 \mathrm{~m}$. The third group, the rest of the stations including B-1 B-6, are located between $120.24^{\circ} \mathrm{E}$ and $120.30^{\circ} \mathrm{E}$. The $\mathrm{O}_{3}$ concentrations measured by these monitoring stations were compared to the simulated $\mathrm{O}_{3}$ concentrations from WRFChem. In addition, the Magong station (OS-1), the fourth group, was selected as a reference air quality station since it was located on a small-flat island in the Taiwan Strait.

\section{Results}

3.1. $\mathrm{O}_{3}$ Concentration Variation Profiles in the Ambient Air of Southwestern Taiwan before Typhoon Arrives. Figure 3 depicts $\mathrm{O}_{3}$ concentration profiles for four air quality monitoring stations (OS-1, O-4, B-5, and M-3) between 96 hours before and 24 hours after issuing sea warnings for both typhoons Nanmadol (red line) and Usagi (blue line). Generally, sea warnings of typhoon are issued 1.0 2.0 days before landing of typhoons. As shown in both Tables 3 and 4 , it was observed that $\mathrm{O}_{3}$ concentration could reach as high as $140 \mathrm{ppb}$ during the investigated period, which was about 2 3-fold higher than normal $\mathrm{O}_{3}$ in summer periods. Similar $\mathrm{O}_{3}$ concentration variation patterns were observed for both cases. The observations also indicated that the $\mathrm{O}_{3}$ concentration periodically reached its daily peak at noon, which was because that $\mathrm{O}_{3}$ was one of the important photochemical reaction products by reacting $\mathrm{NO}_{x}$ with volatile organic compounds under illumination of solar light. $\mathrm{O}_{3}$ commonly exhibits a peak concentration under strong solar radiation at noon.

Besides, for these cases, it was found that $\mathrm{O}_{3}$ concentrations at about 4 days before issuing sea warning were a little bit higher than its normal concentration in summer. The average peak $\mathrm{O}_{3}$ concentrations in the ambient air of Southern Taiwan during summer were about $35 \sim 45 \mathrm{ppb}$. As a matter of fact, in addition to being as a photochemical reaction product, ambient $\mathrm{O}_{3}$ concentration also can be substantially affected by dispersion conditions in the nearground atmosphere. The presence of high air pollutant concentrations often correlates with low atmospheric dispersion. Particularly during summer, low atmospheric dispersion in the near-ground atmosphere is often observed in eastern Asia while shrouded by the WPSH. In this study, for the period about 4 days before issuing sea warning as shown in Figure 3, the WPSH system shrouded most of eastern Asia including the Taiwan Strait and southwestern Taiwan (Figures 4 and 5). Consequently, the $\mathrm{O}_{3}$ concentration maintained a relatively high level during the initial period. 
TABLE 3: Ozone daily peak concentration observed using air quality monitoring stations located in Southern Taiwan before and after the invasion of typhoon Nanmadol (August 24-28, 2011).

\begin{tabular}{|c|c|c|c|c|c|c|}
\hline \multirow{3}{*}{ Air quality station } & \multirow{3}{*}{ Position (Lat/Lon) } & \multicolumn{5}{|c|}{ Daily peak $\mathrm{O}_{3}$ concentrations (unit: $\mathrm{ppb}$ ) } \\
\hline & & August 24 & August 25 & August 26 & August 27 & August $28^{*}$ \\
\hline & & $\begin{array}{l}4 \text { days before } \\
\text { sea warning }\end{array}$ & $\begin{array}{l}3 \text { days before } \\
\text { sea warning }\end{array}$ & $\begin{array}{l}2 \text { days before } \\
\text { sea warning }\end{array}$ & $\begin{array}{l}1 \text { day before } \\
\text { sea warning }\end{array}$ & $\begin{array}{l}\text { Issuing sea } \\
\text { warning }\end{array}$ \\
\hline \multicolumn{7}{|c|}{ Near mountain stations } \\
\hline (M-1) Meinong & $\begin{array}{c}22^{\circ} 53^{\prime} 00.9^{\prime \prime}(\mathrm{N}) \\
120^{\circ} 31^{\prime} 49.95^{\prime \prime}(\mathrm{E})\end{array}$ & 52 & 70 & $95^{*}$ & 75 & 25 \\
\hline (M-2) Chaozhou & $\begin{array}{c}22^{\circ} 31^{\prime} 23.19^{\prime \prime}(\mathrm{N}) \\
120^{\circ} 33^{\prime} 40.23^{\prime \prime}(\mathrm{E})\end{array}$ & 67 & 85 & $88^{*}$ & 77 & 31 \\
\hline (M-3) Pingtung & $\begin{array}{l}22^{\circ} 40^{\prime} 23.09^{\prime \prime}(\mathrm{N}) \\
120^{\circ} 29^{\prime} 16.92^{\prime \prime}(\mathrm{E})\end{array}$ & 46 & 83 & $128^{*}$ & 86 & 38 \\
\hline \multicolumn{7}{|c|}{ Between ocean and mountain group } \\
\hline (B-1) Qiaotou & $\begin{array}{c}22^{\circ} 45^{\prime} 27.02^{\prime \prime}(\mathrm{N}) \\
120^{\circ} 18^{\prime} 20.48^{\prime \prime}(\mathrm{E})\end{array}$ & 65 & 74 & $114^{*}$ & 78 & 56 \\
\hline (B-2) Nanzi & $\begin{array}{c}22^{\circ} 44^{\prime} 1.20^{\prime \prime}(\mathrm{N}) \\
120^{\circ} 19^{\prime} 41.84^{\prime \prime}(\mathrm{E})\end{array}$ & 58 & 74 & $112^{*}$ & 74 & 51 \\
\hline (B-3) Renwu & $\begin{array}{c}22^{\circ} 41^{\prime} 20.6^{\prime \prime}(\mathrm{N}) \\
120^{\circ} 19^{\prime} 57.47^{\prime \prime}(\mathrm{E})\end{array}$ & 55 & 75 & $105^{*}$ & 91 & 49 \\
\hline (B-4) Fengshan & $\begin{array}{l}22^{\circ} 37^{\prime} 38.61^{\prime \prime}(\mathrm{N}) \\
120^{\circ} 21^{\prime} 29.10^{\prime \prime}(\mathrm{E})\end{array}$ & 51 & 81 & $95^{*}$ & 71 & 50 \\
\hline (B-5) Dailao & $\begin{array}{l}22^{\circ} 33^{\prime} 56.69^{\prime \prime}(\mathrm{N}) \\
120^{\circ} 25^{\prime} 30.3^{\prime \prime}(\mathrm{E})\end{array}$ & 65 & 90 & $127^{*}$ & 80 & 43 \\
\hline \multicolumn{7}{|c|}{ Near ocean stations } \\
\hline (O-1) Zuoying & $\begin{array}{l}22^{\circ} 40^{\prime} 29.50^{\prime \prime}(\mathrm{N}) \\
120^{\circ} 17^{\prime} 34.50^{\prime \prime}(\mathrm{E})\end{array}$ & 59 & 77 & $103^{*}$ & 93 & 58 \\
\hline$(\mathrm{O}-2)$ Qianjin & $\begin{array}{l}22^{\circ} 37^{\prime} 57.24^{\prime \prime}(\mathrm{N}) \\
120^{\circ} 17^{\prime} 17.11^{\prime \prime}(\mathrm{E})\end{array}$ & 56 & 69 & $103^{*}$ & 83 & 55 \\
\hline (O-3) Qianzhen & $\begin{array}{l}22^{\circ} 36^{\prime} 19.39^{\prime \prime}(\mathrm{N}) \\
120^{\circ} 18^{\prime} 27.23^{\prime \prime}(\mathrm{E})\end{array}$ & 46 & 60 & $87^{*}$ & 71 & 49 \\
\hline$(\mathrm{O}-4)$ Linyuan & $\begin{array}{l}22^{\circ} 28^{\prime} 46.2^{\prime \prime}(\mathrm{N}) \\
120^{\circ} 24^{\prime} 42.3^{\prime \prime}(\mathrm{E})\end{array}$ & 80 & 73 & $100^{*}$ & 69 & 45 \\
\hline (O-5) Xiaogang & $\begin{array}{l}22^{\circ} 33^{\prime} 57.00^{\prime \prime}(\mathrm{N}) \\
120^{\circ} 20^{\prime} 15.85^{\prime \prime}(\mathrm{E})\end{array}$ & 51 & 73 & $92^{*}$ & 63 & 52 \\
\hline \multicolumn{7}{|c|}{ Oversea station } \\
\hline (OS-1) Magong & $\begin{array}{c}23^{\circ} 34^{\prime} 8.51^{\prime \prime}(\mathrm{N}) \\
119^{\circ} 33^{\prime} 58.17^{\prime \prime}(\mathrm{E})\end{array}$ & 28 & $79^{*}$ & 45 & 61 & 48 \\
\hline
\end{tabular}

p.s.: * occurrence of peak $\mathrm{O}_{3}$ concentration from -90 to $+24 \mathrm{hrs}$.

For these two cases examined here, the highest $\mathrm{O}_{3}$ concentration congruously occurred in the afternoon 1.0 2.0 days before the issuing of sea warnings for both typhoons. This was attributable to the decreasing wind speeds observed in southwestern Taiwan and the intensified wind speeds observed in the Taiwan Strait when the WPSH system decreased in strength and the typhoons moved into Southern Taiwan. The former effect resulted in increasing ambient $\mathrm{O}_{3}$ concentration in southwestern Taiwan, and the latter effect resulted in decreased $\mathrm{O}_{3}$ concentration in the ambient air of the Taiwan Strait. The low air quality occurring in southwestern Taiwan was attributed to the forming of atmospheric subsidence in southwestern Taiwan. The atmospheric subsidence resulted from the formation of leeward side effects in southwestern Taiwan when outer-region circulations of the typhoon made contact with the high mountains located on the east side of southwestern Taiwan. Because of the approaching typhoon, on the other hand, the mechanical mixing mechanisms in the atmosphere of the Taiwan Strait were intensified, causing low $\mathrm{O}_{3}$ concentration in the ambient air.

Furthermore, Figure 6 compares the variation profiles of monitored and modeled $\mathrm{O}_{3}$ concentrations for the four represented air quality monitoring stations. The simulated $\mathrm{O}_{3}$ concentration was achieved from the WRF-Chem modeling. Highly correlated relationships were found between simulated and observed results. Their correlation coefficients were higher than 0.8 (see Figure 7 ). The simulated results were mostly consistent with the observed $\mathrm{O}_{3}$ concentrations, but the simulated results may underestimate the observed peak $\mathrm{O}_{3}$ concentrations in some cases. 
TABLE 4: Ozone daily peak concentration observed using air quality monitoring stations located in Southern Taiwan before and after the invasion of typhoon Usagi (September 16 20, 2013).

\begin{tabular}{|c|c|c|c|c|c|c|}
\hline \multirow{3}{*}{ Air quality station } & \multirow{3}{*}{ Position (Lat/Lon) } & \multicolumn{5}{|c|}{ Daily peak $\mathrm{O}_{3}$ concentrations (unit: $\mathrm{ppb}$ ) } \\
\hline & & September 16 & September 17 & September 18 & September 19 & September $20^{*}$ \\
\hline & & $\begin{array}{l}4 \text { days before } \\
\text { sea warning }\end{array}$ & $\begin{array}{c}3 \text { days before } \\
\text { sea warning }\end{array}$ & $\begin{array}{c}2 \text { days before } \\
\text { sea warning }\end{array}$ & $\begin{array}{l}1 \text { day before } \\
\text { sea warning }\end{array}$ & $\begin{array}{c}\text { Issuing sea } \\
\text { warning }\end{array}$ \\
\hline \multicolumn{7}{|c|}{ Near mountain stations } \\
\hline (M-1) Meinong & $\begin{array}{c}22^{\circ} 53^{\prime} 00.9^{\prime \prime}(\mathrm{N}) \\
120^{\circ} 31^{\prime} 49.95^{\prime \prime}(\mathrm{E})\end{array}$ & 55 & 64 & 108 & $121^{*}$ & 64 \\
\hline (M-2) Chaozhou & $\begin{array}{c}22^{\circ} 31^{\prime} 23.19^{\prime \prime}(\mathrm{N}) \\
120^{\circ} 33^{\prime} 40.23^{\prime \prime}(\mathrm{E})\end{array}$ & 52 & 83 & $141^{*}$ & 90 & 101 \\
\hline (M-3) Pingtung & $\begin{array}{l}22^{\circ} 40^{\prime} 23.09^{\prime \prime}(\mathrm{N}) \\
120^{\circ} 29^{\prime} 16.92^{\prime \prime}(\mathrm{E})\end{array}$ & 61 & 82 & 127 & $134^{*}$ & 86 \\
\hline \multicolumn{7}{|c|}{ Between ocean and mountain group } \\
\hline (B-1) Qiaotou & $\begin{array}{c}22^{\circ} 45^{\prime} 27.02^{\prime \prime}(\mathrm{N}) \\
120^{\circ} 18^{\prime} 20.48^{\prime \prime}(\mathrm{E})\end{array}$ & 71 & 67 & $117^{*}$ & 101 & 79 \\
\hline (B-2) Nanzi & $\begin{array}{c}22^{\circ} 44^{\prime} 1.20^{\prime \prime}(\mathrm{N}) \\
120^{\circ} 19^{\prime} 41.84^{\prime \prime}(\mathrm{E})\end{array}$ & 60 & 64 & $119^{*}$ & 100 & 84 \\
\hline (B-3) Renwu & $\begin{array}{c}22^{\circ} 41^{\prime} 20.6^{\prime \prime}(\mathrm{N}) \\
120^{\circ} 19^{\prime} 57.47^{\prime \prime}(\mathrm{E})\end{array}$ & 58 & 56 & $111^{*}$ & 88 & 78 \\
\hline (B-4) Fengshan & $\begin{array}{l}22^{\circ} 37^{\prime} 38.61^{\prime \prime}(\mathrm{N}) \\
120^{\circ} 21^{\prime} 29.10^{\prime \prime}(\mathrm{E})\end{array}$ & 44 & 66 & $134^{*}$ & 90 & 83 \\
\hline (B-5) Dailao & $\begin{array}{l}22^{\circ} 33^{\prime} 56.69^{\prime \prime}(\mathrm{N}) \\
120^{\circ} 25^{\prime} 30.3^{\prime \prime}(\mathrm{E})\end{array}$ & 50 & 79 & $142^{*}$ & 109 & 86 \\
\hline \multicolumn{7}{|c|}{ Near ocean stations } \\
\hline (O-1) Zuoying & $\begin{array}{l}22^{\circ} 40^{\prime} 29.50^{\prime \prime}(\mathrm{N}) \\
120^{\circ} 17^{\prime} 34.50^{\prime \prime}(\mathrm{E})\end{array}$ & 77 & 71 & $134^{*}$ & 97 & 74 \\
\hline (O-2) Qianjin & $\begin{array}{l}22^{\circ} 37^{\prime} 57.24^{\prime \prime}(\mathrm{N}) \\
120^{\circ} 17^{\prime} 17.11^{\prime \prime}(\mathrm{E})\end{array}$ & 65 & 55 & $117^{*}$ & 87 & 70 \\
\hline (O-3) Qianzhen & $\begin{array}{l}22^{\circ} 36^{\prime} 19.39^{\prime \prime}(\mathrm{N}) \\
120^{\circ} 18^{\prime} 27.23^{\prime \prime}(\mathrm{E})\end{array}$ & 65 & 66 & $110^{*}$ & 92 & 65 \\
\hline (O-4) Linyuan & $\begin{array}{l}22^{\circ} 28^{\prime} 46.2^{\prime \prime}(\mathrm{N}) \\
120^{\circ} 24^{\prime} 42.3^{\prime \prime}(\mathrm{E})\end{array}$ & 48 & 91 & $113^{*}$ & 80 & 70 \\
\hline$(\mathrm{O}-5)$ Xiaogang & $\begin{array}{c}22^{\circ} 33^{\prime} 57.00^{\prime \prime}(\mathrm{N}) \\
120^{\circ} 20^{\prime} 15.85^{\prime \prime}(\mathrm{E})\end{array}$ & 59 & 68 & $113^{*}$ & 87 & 68 \\
\hline \multicolumn{7}{|c|}{ Oversea station } \\
\hline (OS-1) Magong & $\begin{array}{c}23^{\circ} 34^{\prime} 8.51^{\prime \prime}(\mathrm{N}) \\
119^{\circ} 33^{\prime} 58.17^{\prime \prime}(\mathrm{E})\end{array}$ & 68 & $75^{*}$ & 70 & 43 & 39 \\
\hline
\end{tabular}

p.s.: ${ }^{*}$ occurrence of peak $\mathrm{O}_{3}$ concentration from -90 to $+24 \mathrm{hrs}$.

In terms of the $\mathrm{O}_{3}$ concentration variation patterns shown in Figure 6, the $\mathrm{O}_{3}$ concentration of the offshore station (OS1) faded fast as the approach of both typhoons, indicating the leeside effect for OS-1 station was not as strong as inland stations. For the Nanmadol case, since the moving track for Nanmadol was more northern than Usagi, typhoon Nanmadol reduced its strength after landing in Taiwan. The weather conditions around OS-1 station backed to usual summer weather conditions quickly. But for the Usagi case, Usagi did not really land in Taiwan; its strength did not reduce too much while passing the Bashi Channel. So, the nearground wind speeds for OS-1 increased while typhoons were approaching and $\mathrm{O}_{3}$ concentration decreased fast.

On the other hand, for O-4, B-5, and M-3, forming high $\mathrm{O}_{3}$ concentrations within inland areas was because that $\mathrm{O}_{3}$ progressively increased its concentration as typhoons approached. Among the proposed inland air quality monitoring stations, $\mathrm{O}-4$ had the highest $\mathrm{O}_{3}$ concentration, which occurred approximately 1 1.5 days before the issuing of typhoon sea warnings. Similarly, the highest $\mathrm{O}_{3}$ concentrations for B-5 and M-3 took place approximately 1.0 day before the issuing of typhoon sea warnings. M-3 belongs to the mountain group air quality monitoring stations and B-5 is located between the ocean and mountain group stations.

All of these mentioned results indicated the accumulation of $\mathrm{O}_{3}$ in the region due to the occurrence of strong leeward side effects in southwestern Taiwan while the typhoons approached from the other side of the mountains. The $\mathrm{O}_{3}$ concentration increased to a high level when the typhoons were approaching but decreased when the typhoons were sufficiently close to Taiwan to significantly enhance surface wind speeds. As shown in Tables 3 and 4, the atmospheric 

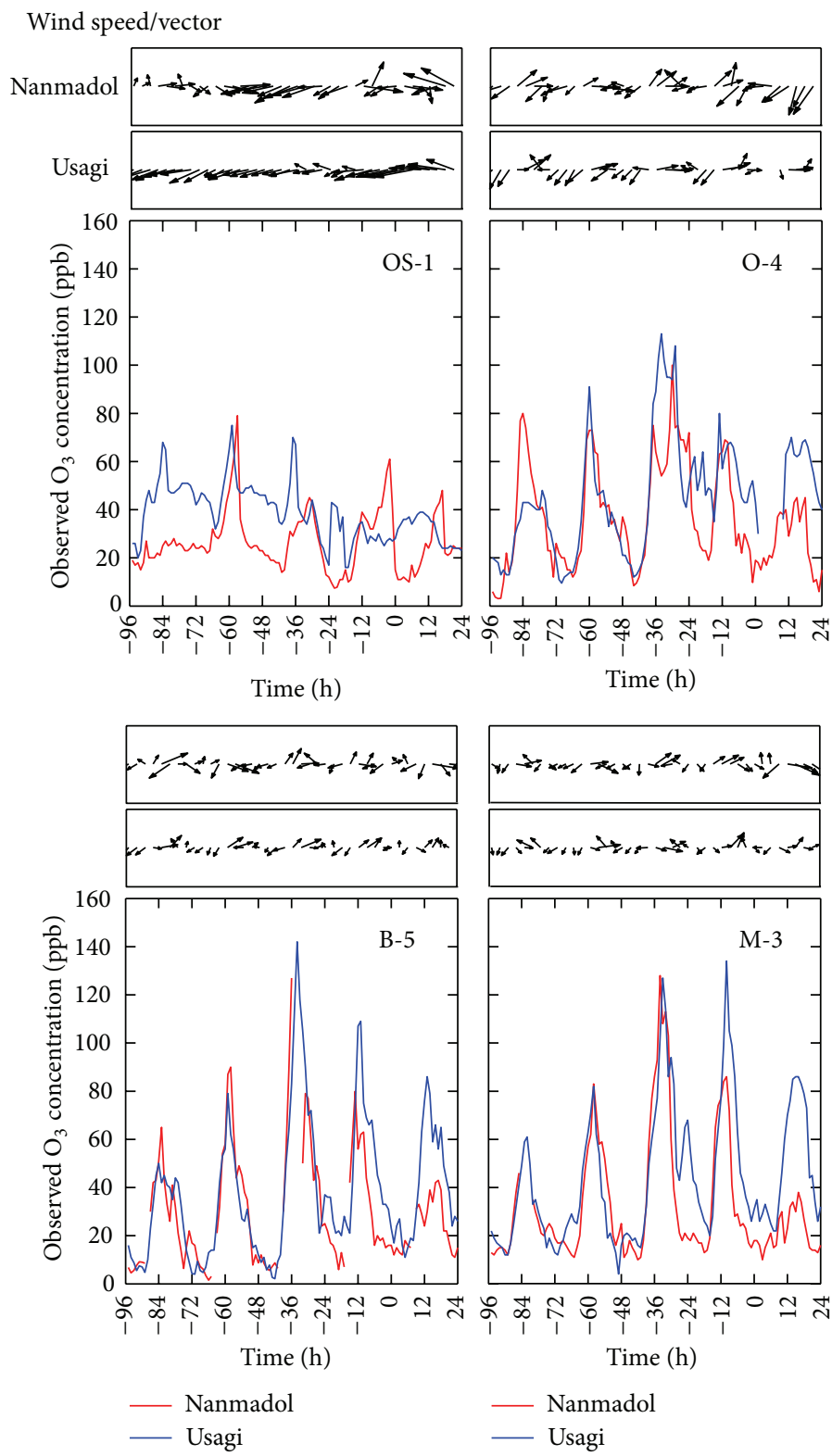

FIGURE 3: Observed ozone concentration in the ambient air before and after the invasion of typhoon Nanmadol (August 24 28, 2011) and typhoon Usagi from September 16 to 20, 2013. (Time $=0$ is the time for issuing sea warning for typhoons.)

subsidence resulted in $\mathrm{O}_{3}$ concentrations reaching up to 2 3fold higher than the normal concentration.

\subsection{Weather Systems in Southern Taiwan before Typhoon Invasions}

3.2.1. Typhoon Nanmadol Invasion Case in 2011. Figure 8 depicts the skew-temperature diagrams of two air quality monitoring stations, OS-1 and O-1, in the afternoon of August 26 and 27, 2011, which was approximately 1 2 days before issuing the sea warning for typhoon Nanmadol. The OS-1 station was established on a small, flat island in the Taiwan Strait, the weather of which represents the synoptic-scale weather of Taiwan. However, the O-1 station is located in the inland area of southwestern Taiwan. Because of the complicated geological characteristics of Taiwan, the microweather around the inland air quality stations may differ from the synoptic-scale weather of Taiwan. For instance, atmospheric subsidence that typically forms in western Taiwan resulted from leeward side effects while strong eastern air streams are blocked by the high mountains located in Eastern Taiwan (Figures 1 and 4).

Based on the skew-temperature diagrams of OS-1 (Figure 8), in the afternoon of August 26 and 27 particularly, the weather was cloudless with prevailing eastern or northeastern breezes in the atmosphere above $500 \mathrm{hpa}$, which was a typical WPSH weather pattern. One of the most concerned for WPSH during summer periods is to cause low ambient air quality within its shrouding area [31]. In 

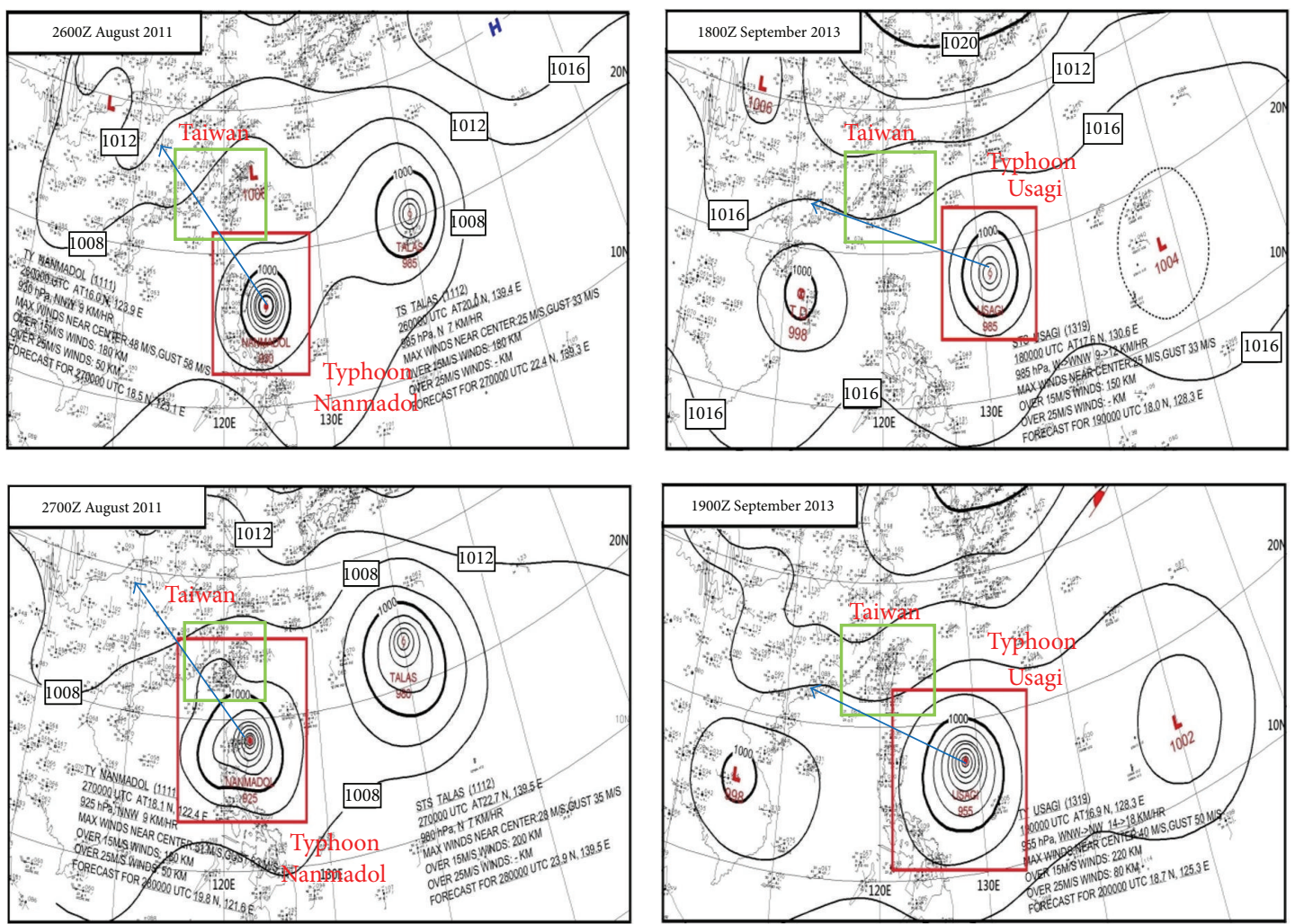

FIGURE 4: Surface weather charts for typhoons Nanmadol and Usagi (data from Taiwan CWB).

this study, atmospheric subsidence in the middle and high level atmosphere was observed. Therefore, in this study, the low air quality observed in the Southern Taiwan Strait about 4 days before typhoons arrive was mainly caused by the WPSH weather system shrouding this area (Figure 5). Poor atmospheric dispersion occurred in the ambient air, which was consistent with the observations of high $\mathrm{O}_{3}$ concentration during the same period as shown in Figure 3.

Moreover, based on the skew-temperature diagrams of O-1, the temperature inversion above southwestern Taiwan was not as significant as that shown in OS-1, but atmospheric subsidence formed as well, which was because the WPSH system above southwestern Taiwan was not strong and typhoon Nanmadol began to move into Taiwan. Prevailing eastern or northeastern breezes blew toward Taiwan in the atmosphere above 900 hpa above O-1. The atmospheric humidity was low. Therefore, during this particular period (August 26 and 27), the near-ground atmospheric structures in southwestern Taiwan (<200 hpa) were stable and dispersion of air pollutants in the ambient air was limited. The outer-region circulation of typhoon Nanmadol made contact with the high mountains located in Eastern Taiwan, causing atmospheric subsidence that occurred in the atmosphere above southwestern Taiwan. Therefore, during the later period before arrival of typhoon Nanmadol, the synergetic effects of weakening of the WPSH and intensifying of the leeward side effects resulted in stable atmospheric conditions but low ambient air quality in southwestern Taiwan (see Figure 3).
3.2.2. Typhoon Usagi Invasion Case in 2013. The invasion of typhoon Usagi essentially had similar metrological patterns as the invasion of typhoon Nanmadol. But, there were still some differences in WPSH strength between them. The WPSH system in the Usagi case was stronger than that in the Nanmadol case (Figure 5). Instead of directly landing in Taiwan, the center of Typhoon Usagi passed Taiwan through the Bashi Channel (Figures 1 and 4). However, the outerregion circulations of Usagi still made contact with the high mountains of Southern Taiwan. Atmospheric subsidence also occurred in southwestern Taiwan, and low ambient air quality was shown in southwestern Taiwan.

Figure 9 depicts the skew-temperature diagrams for OS1 and O-1 in the afternoon of September 18 and 19, 2013, which was 2 3 days before typhoon Usagi arrived in Taiwan. As discussed earlier in this paper, the weather system of Magong (OS-1) can represent the synoptic-scale weather system around Taiwan, and the inland microweather system for southwestern Taiwan can be affected by the leeward side effects. Before Usagi approached Taiwan, the air humidity in the atmosphere at both middle and high levels was low. The atmosphere was stable. Because of the WPSH system shrouding Southern Taiwan (Figure 5), a temperature inversion layer formed in the atmosphere below 500 hpa. Prevailing northeastern or northwestern winds were observed in the atmosphere above $500 \mathrm{hpa}$ and prevailing eastern winds were observed in the atmosphere between 300 and 500 hpa. Atmospheric subsidence occurred in the ambient air of 

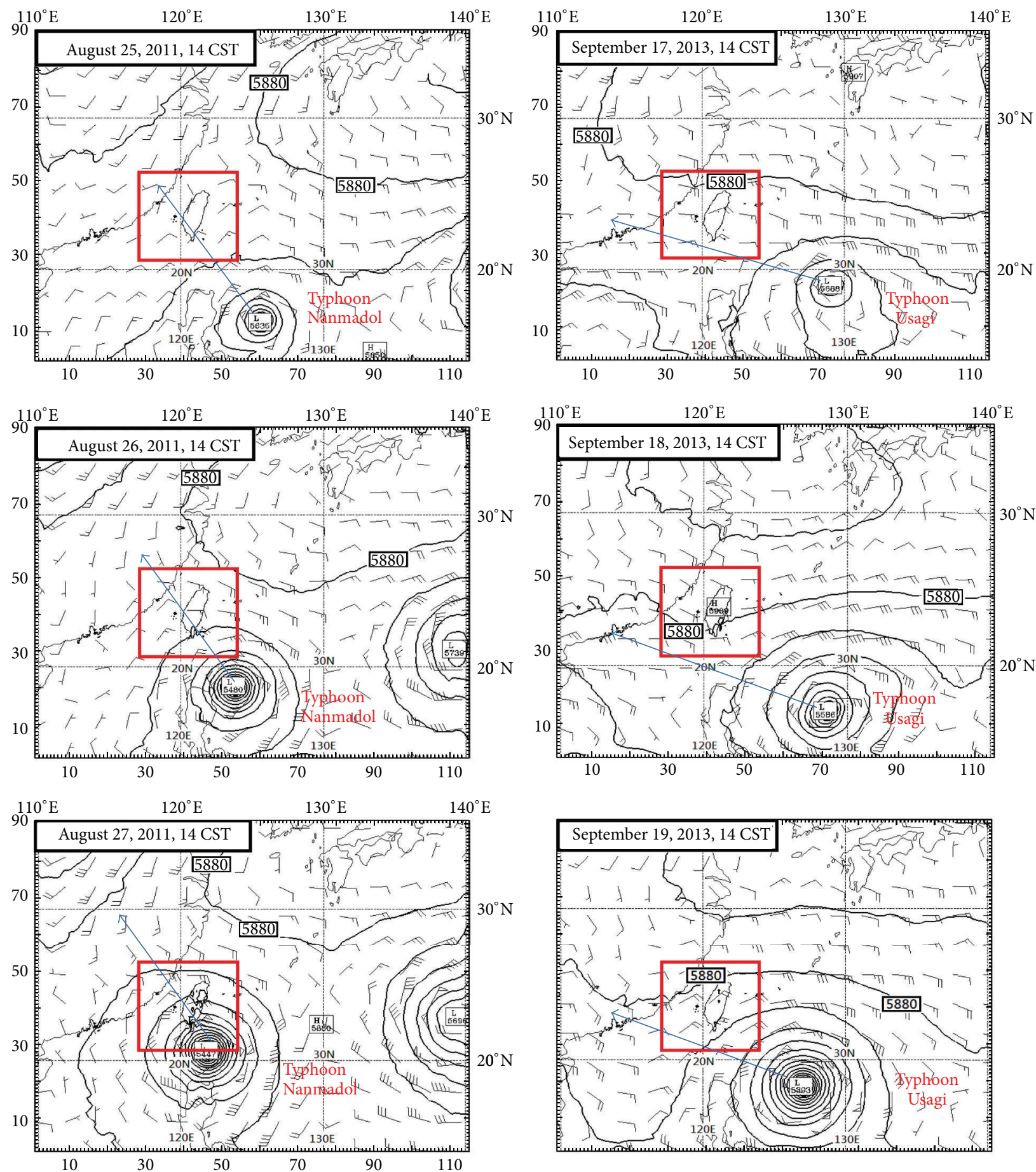

FIGURE 5: Modeled geopotential height weather charts and horizontal wind vectors (m/s) at 500 hpa model level around Taiwan.

southwestern Taiwan. Stable weather covered both offshore and inland areas of Taiwan. This kind of stable weather system and the lack of vertical mixing mechanisms provided a favorable environment for the photochemical formation of $\mathrm{O}_{3}$, but the environment was unfavorable for $\mathrm{O}_{3}$ to disperse in the ambient air. Air pollutants in such low humidity and weak convection environments tend to accumulate in the atmosphere below $500 \mathrm{hpa}$. Low air quality was observed in the ambient air of Southern Taiwan before Usagi really arrived in Taiwan.

\section{Discussion}

4.1. Formation Mechanisms of Highly Concentrated $\mathrm{O}_{3}$ and Its Fading Pattern during the Course of Typhoon Movement. Figure 10 illustrates the simulated $\mathrm{O}_{3}$ concentration contours 
OS-1 station

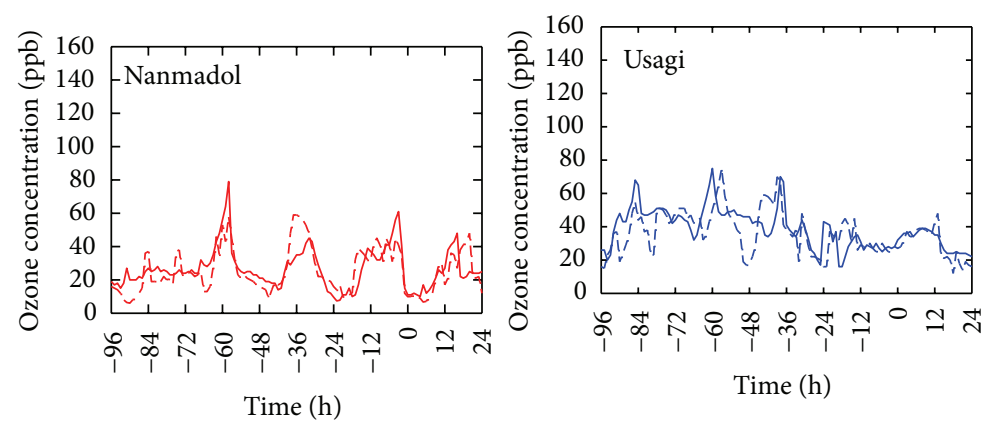

O-4 station
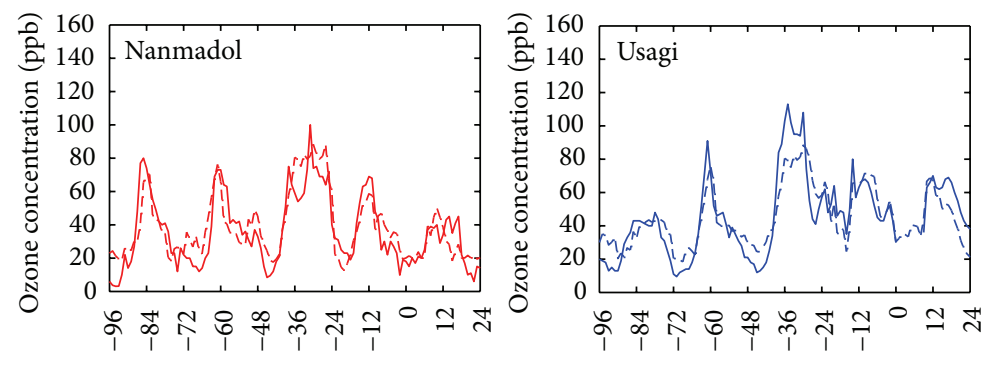

Time (h)

Time (h)
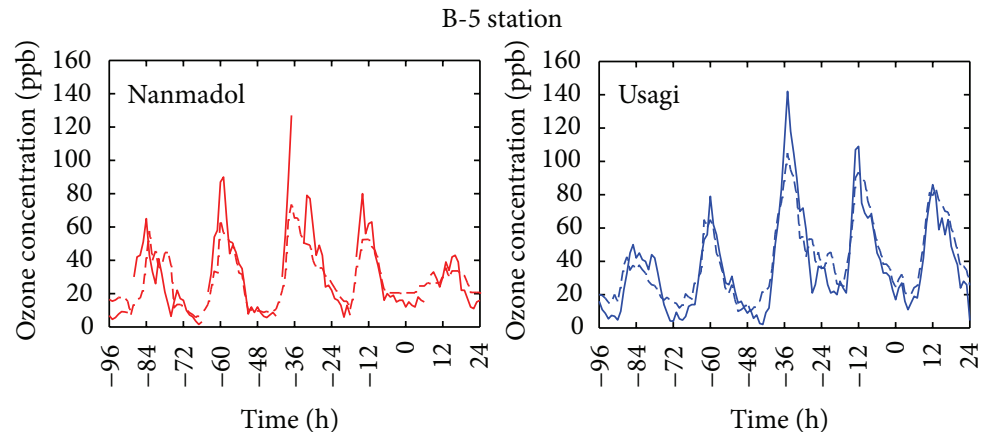

M-3 station

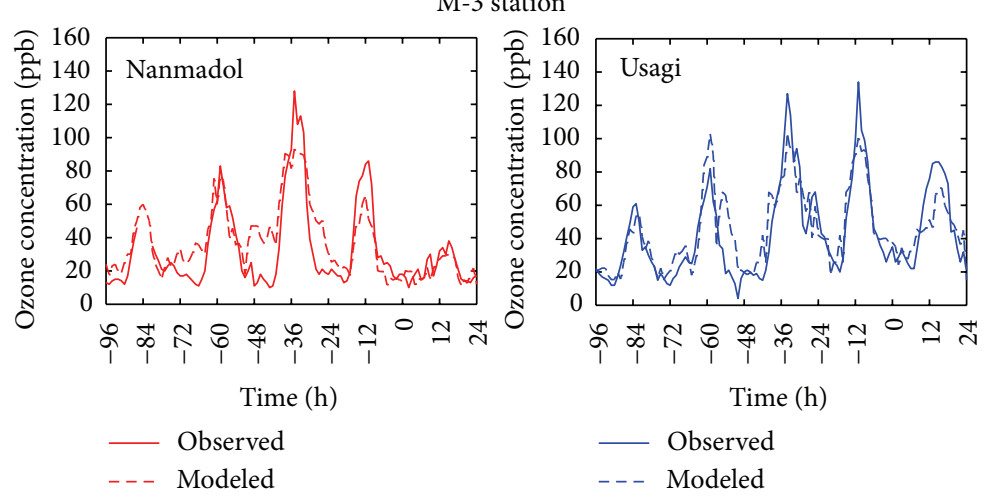

Figure 6: Both observed (O) and modeled (M) ozone concentration in the ambient air in Southern Taiwan before and after issuing sea warning for both typhoons Nanmadol and Usagi (August 24 28, 2011, for Nanmadol and September 16 20, 2013, for Usagi); Magong (OS-1), Linyuan (O-4), Dailao (B-5), and Pingtung (M-3) stations. (Time $=0$ is the time for issuing sea warning for typhoons.)

in the ambient air of southwestern Taiwan before both invasions of typhoons Nanmadol and Usagi. The major weather systems for both typhoons were affected by the WPSH during the periods of 3 4 days before issuing sea warning, but the WPSH system for the Usagi case was stronger than that for Nanmadol case. Instead of directly landing in Taiwan, which was the course of Typhoon Nanmadol, typhoon Usagi moved through the Bashi Channel, and its center did not really land in Taiwan. Moreover, the formation of atmospheric subsidence in southwestern Taiwan was observed in both cases when the WPSH system withdrew from Taiwan, and the typhoons invaded Taiwan. 

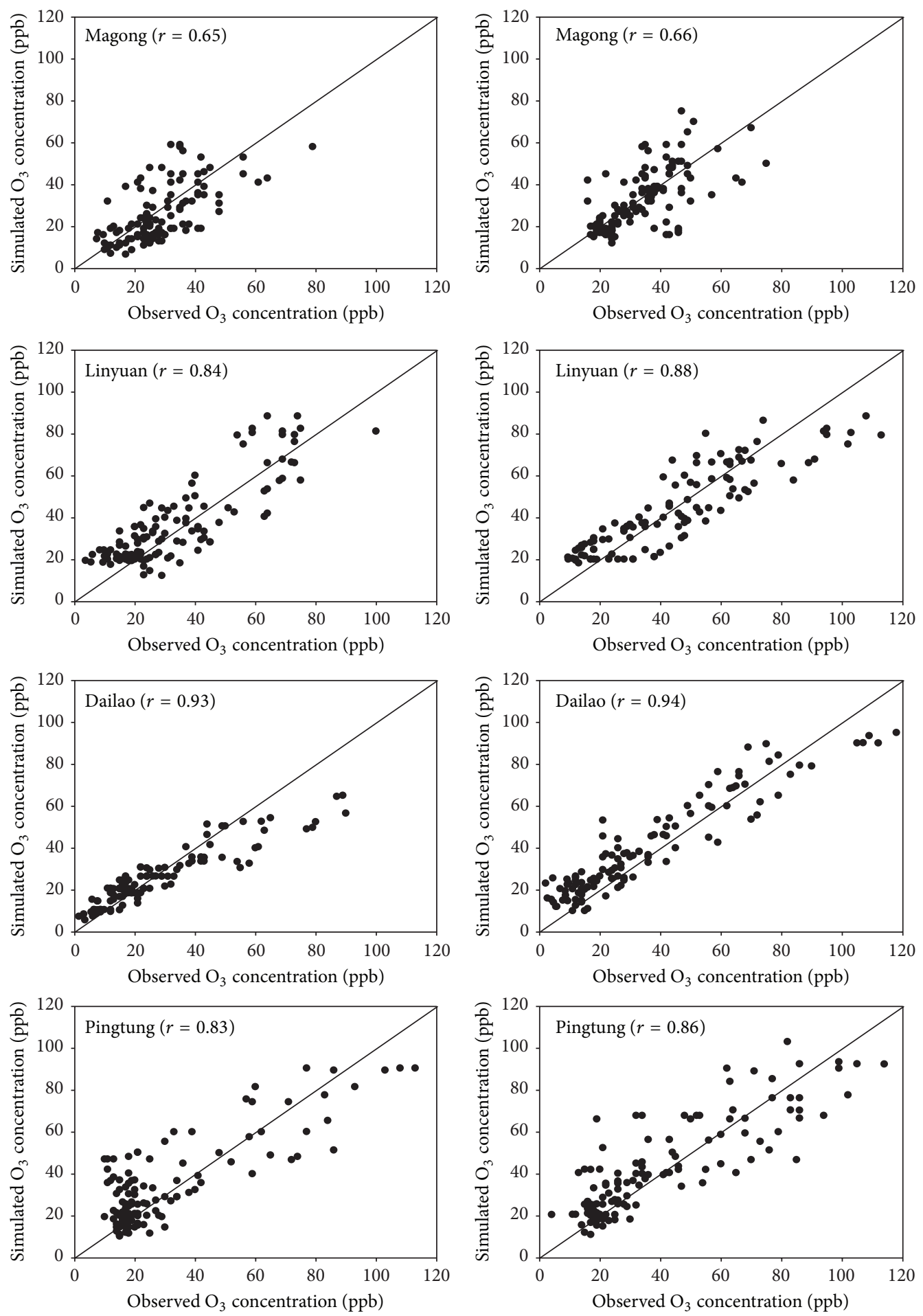

(a)

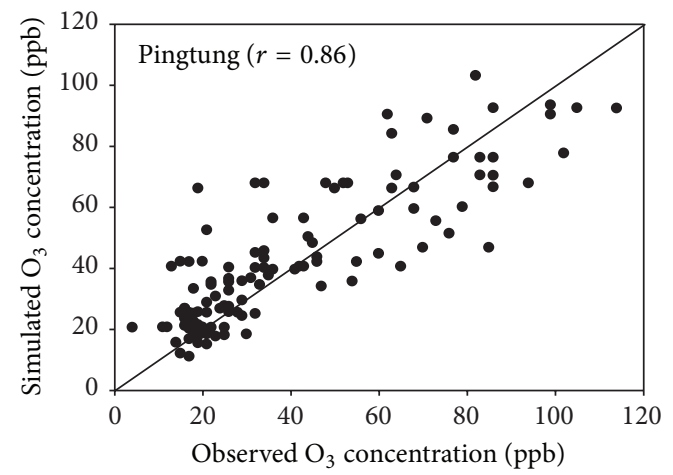

(b)

FIGURE 7: Relationships of simulated and observed $\mathrm{O}_{3}$ concentration in the ambient air Southern Taiwan ((b) 2013 Usagi; (a) 2011 Nanmadol).

The atmospheric subsidence resulted in the accumulation of $\mathrm{O}_{3}$ in the ambient air. As mentioned in this paper, the low air quality observed about 4 days before issuing sea warning, as shown in Figure 3, was mainly caused by the WPSH weather system shrouding southwestern Taiwan to form a minor atmospheric subsidence. The low air quality for the later period of about 1 2 days before issuing sea warning was mainly caused by the synergetic effects of the weakening of the WPSH and intensifying of the leeward side effects. More substantial atmospheric subsidence was found 

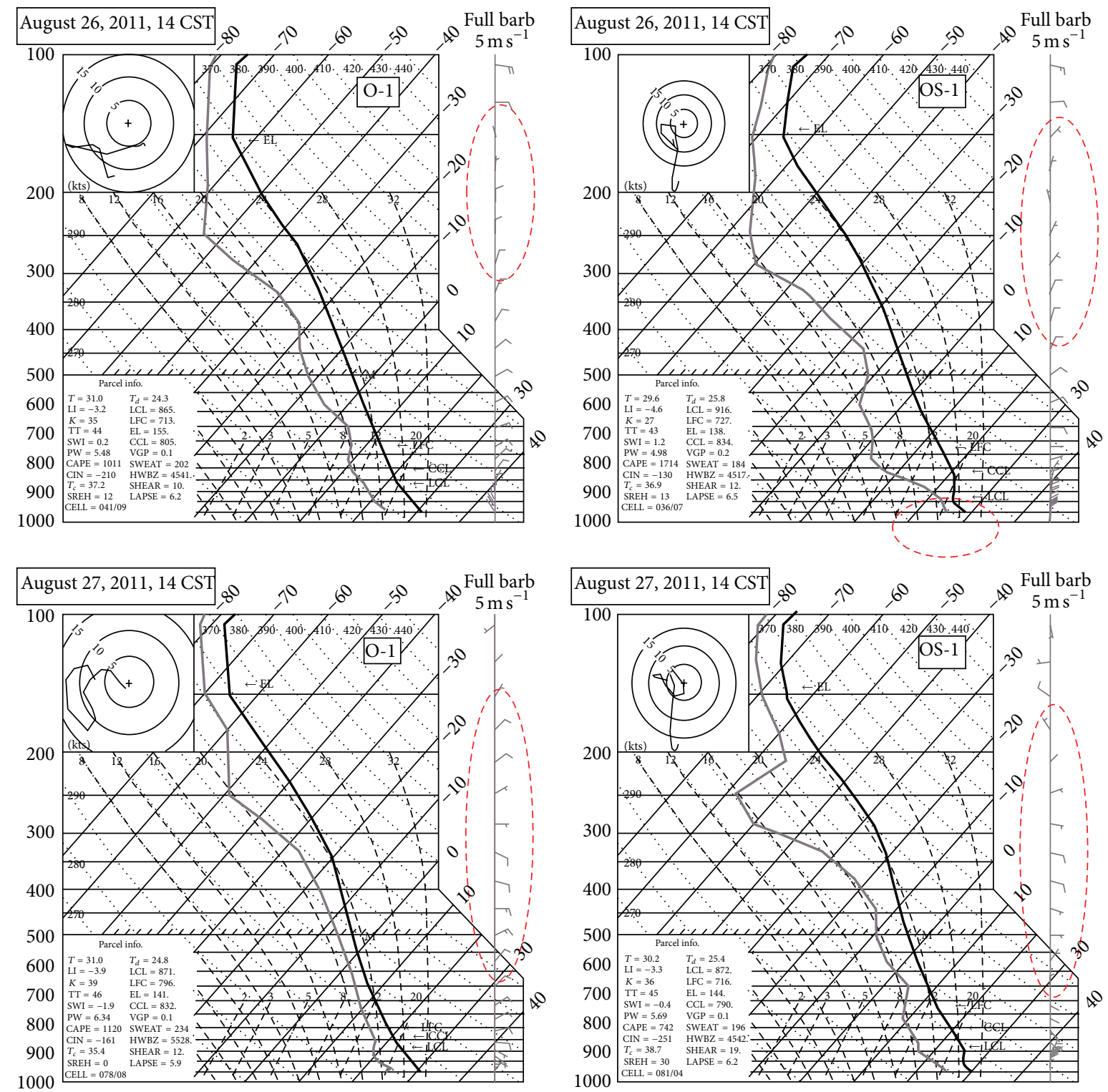

Figure 8: Modeled skew-temperature diagram for Zuoying (O-1) and Magong (OS-1) air quality monitoring stations for the invasion of typhoon Nanmadol (black line: temperature $\left({ }^{\circ} \mathrm{C}\right)$; gray line: dew-point temperature $\left({ }^{\circ} \mathrm{C}\right)$; wind vector full barb $=5 \mathrm{~m} / \mathrm{s}$ ).

approximately 2.0 3.0 days before the real landing of the typhoons. Therefore, in both cases, low ambient air quality occurred when the typhoons approached Taiwan. Typhoon invasions could result in $\mathrm{O}_{3}$ concentrations up to 2 3 times higher than the normal concentration.

However, differences in the $\mathrm{O}_{3}$ concentration fading patterns were found in both cases. As shown on the lefthand side of Figure 10, the results indicated a variation of $\mathrm{O}_{3}$ contours in the Nanmadol case. The $\mathrm{O}_{3}$ concentration was observed to fade from southeast to northwest, which was consistent with the movement of the WPSH. Typhoon Nanmadol followed the fourth pathway. In other words, Nanmadol entered Taiwan from its southeastern corner and moved from southeast to northwest. The movement of this typhoon was consistent with the $\mathrm{O}_{3}$ concentration fading patterns. The peak $\mathrm{O}_{3}$ concentration shifted from southeast to northwest. Alternatively, for the typhoon Usagi case, the course of typhoon Usagi, from east to west, was consistent with the $\mathrm{O}_{3}$ concentration fading patterns, which is shown on the right-hand side of Figure 10. The peak $\mathrm{O}_{3}$ concentration shifted from east to west. The intrinsic mechanism for determining the moving tracks of typhoons is determined by the moving directions of WPSH systems, which also attract the occurrence of peak ozone concentration.

\subsection{Application of the $\mathrm{O}_{3}$ Concentration Time-Increasing and} Space-Fading Patterns as References for Predicting Typhoon Movement. The WPSH dominantly affects the movement of tropical typhoons occurring in the western Pacific Ocean, and highly correlated relationships are found between 

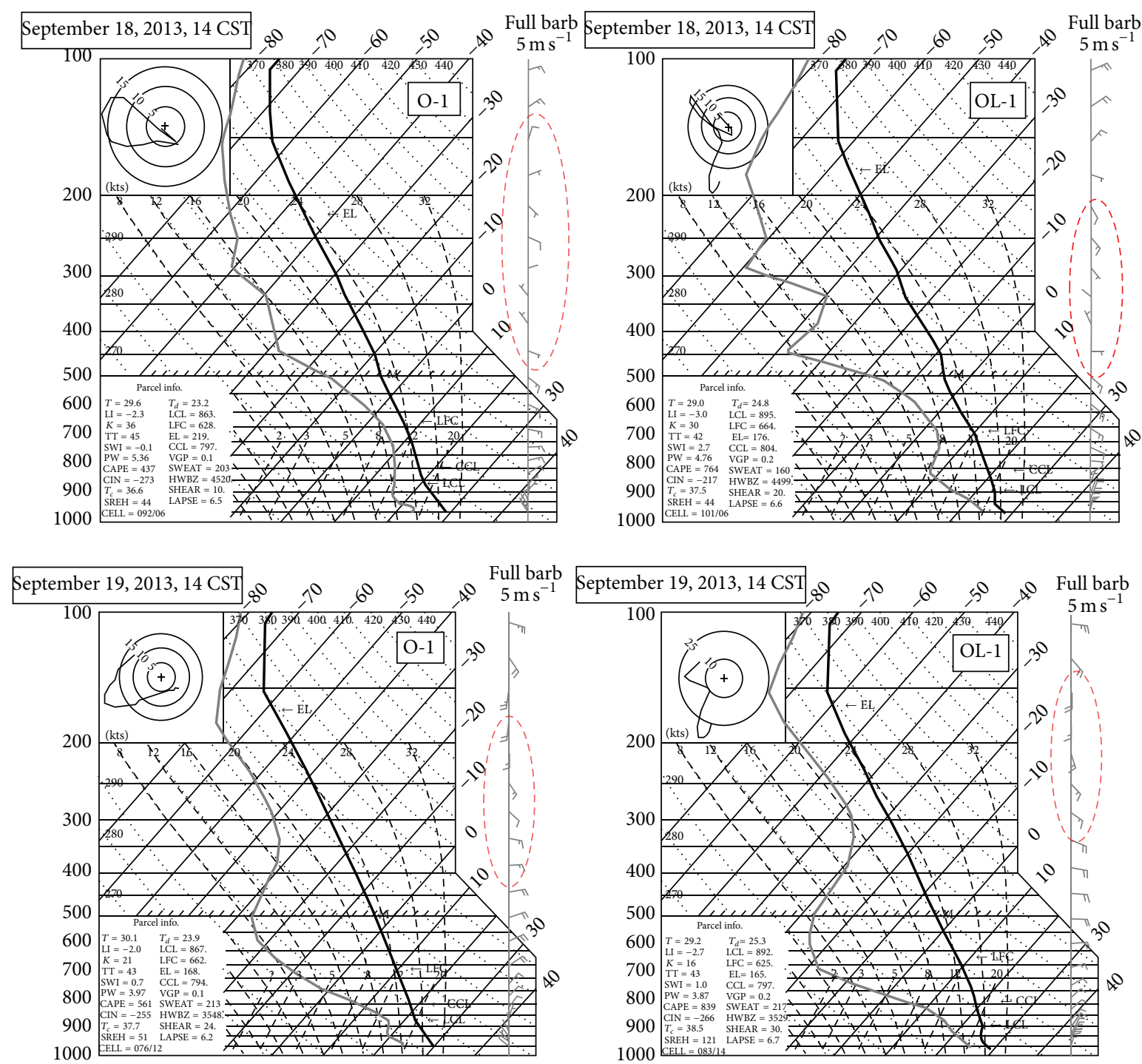

FIgure 9: Modeled skew-temperature diagram for Zuoying (O-1) and Magong (OS-1) air quality monitoring stations for the invasion of typhoon Usagi (black line: temperature $\left({ }^{\circ} \mathrm{C}\right)$; gray line: dew-point temperature $\left({ }^{\circ} \mathrm{C}\right)$; wind vector full barb $=5 \mathrm{~m} / \mathrm{s}$ ).

the position and strength of the WPSH and typhoon movement. In the past, precisely predicting the positions and paths of typhoon invading was difficult. In this study, we found that typhoons did not directly land in Southern Taiwan when the WPSH was strong. When the WPSH decreased in strength and began to move away from Southern Taiwan and the typhoons approached Taiwan, the concentration of $\mathrm{O}_{3}$ progressively increased in the ambient air and reached the highest concentration approximately 1.0 2.0 days before the typhoons arrive. This progressive accumulation of $\mathrm{O}_{3}$ concentration in the ambient air of southwestern Taiwan indicated the invasion of typhoons because southwestern Taiwan is located on the leeward side of the typhoons.

We summarized the correlations among $\mathrm{O}_{3}$ concentrations measured by different inland air quality monitoring stations as shown in Tables 5 and 6 for typhoons Nanmadol and Usagi, respectively, which indicated high correlations among the inland air quality monitoring stations but poor correlation between offshore station (OS-1) and inland stations. Table 5 is correlation coefficient arrays of each station's ozone concentration in 2011. Before describing the intensity of correlation coefficient, the $p$ value should be significant. Once the $p$ value is below 0.05 , it means each station's $\mathrm{O}_{3}$ correlation. In other words, further discussion of the intensity of correlation coefficient is meaningful if the $p$ value is below 0.05 . The $\mathrm{O}_{3}$ correlation coefficient of each station in 2011 had significant level, which showed the existence of mutual relation.

In addition, Table 6 is the correlation coefficient array of each station's ozone concentration in 2013. The ozone concentration of each station had significant level, and OS-1 and M-3 stations are excluded. This showed the other stations have a mutual relation. One thing that should be noticed is the $\mathrm{O}_{3}$ concentration relation between station OS-1 and the others. The average value of correlation between station OS-1 and the others in 2011 is 0.44 . The average value of correlation 

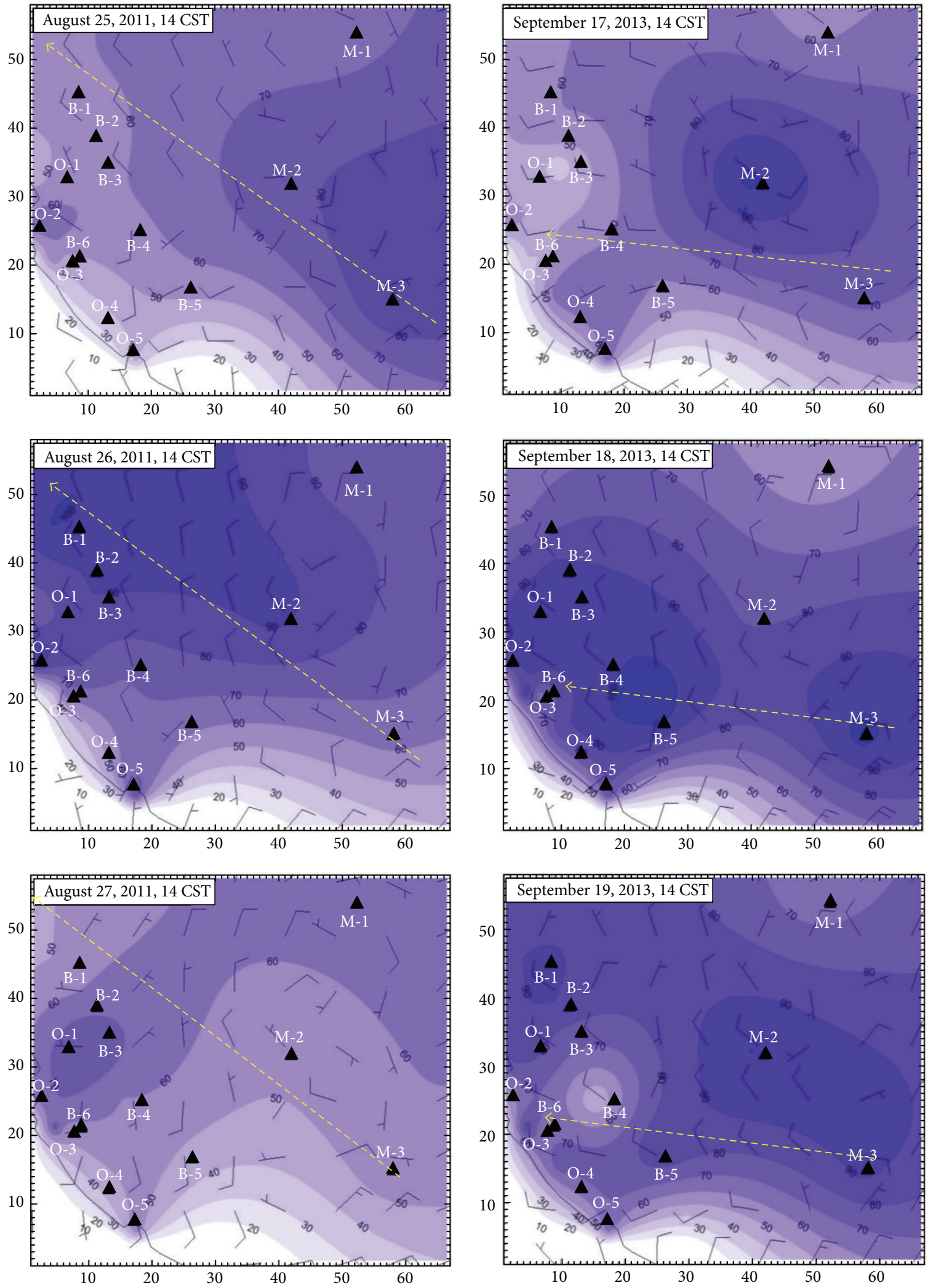

FIGURE 10: Modeled ozone concentration contours in the ambient air of Southern Taiwan during the invasions of typhoons Nanmadol and Usagi. 
TABLE 5: $p$ value and quality for correlation coefficients for $\mathrm{O}_{3}$ concentrations measured by air quality monitoring stations for typhoon Nanmadol invading case.

\begin{tabular}{|c|c|c|c|c|c|c|c|c|c|c|c|c|c|c|}
\hline Station & O-1 & $\mathrm{O}-2$ & $\mathrm{O}-3$ & $\mathrm{O}-4$ & $\mathrm{O}-5$ & M-1 & M-2 & M-3 & B-1 & B-2 & B-3 & B-4 & B-5 & OS-1 \\
\hline O-1 & & $0.95^{* *}$ & $0.90^{* *}$ & $0.71^{* *}$ & $0.86^{* *}$ & $0.81^{* *}$ & $0.82^{* *}$ & $0.90^{* *}$ & $0.96^{* *}$ & $0.95^{* *}$ & $0.94^{* *}$ & $0.93^{* *}$ & $0.85^{* *}$ & $0.41^{* *}$ \\
\hline $\mathrm{O}-2$ & A & & $0.92^{* *}$ & $0.71^{* *}$ & $0.87^{* *}$ & $0.81^{* *}$ & $0.80^{* *}$ & $0.90^{* *}$ & $0.92^{* *}$ & $0.93^{* *}$ & $0.92^{* *}$ & $0.92^{* *}$ & $0.84^{* *}$ & $0.43^{* *}$ \\
\hline $\mathrm{O}-3$ & A & A & & $0.78^{* *}$ & $0.92^{* *}$ & $0.81^{* *}$ & $0.78^{* *}$ & $0.87^{* *}$ & $0.85^{* *}$ & $0.86^{* *}$ & $0.87^{* *}$ & $0.92^{* *}$ & $0.83^{* *}$ & $0.42^{*}$ \\
\hline $\mathrm{O}-4$ & $\mathrm{C}$ & $\mathrm{C}$ & $\mathrm{C}$ & & $0.80^{* *}$ & $0.72^{* *}$ & $0.76^{* *}$ & $0.72^{* *}$ & $0.69^{* *}$ & $0.67^{* *}$ & $0.73^{* *}$ & $0.77^{* *}$ & $0.84^{* *}$ & $0.39^{* *}$ \\
\hline O-5 & B & B & A & B & & $0.75^{* *}$ & $0.77^{* *}$ & $0.84^{* *}$ & $0.80^{* *}$ & $0.81^{* *}$ & $0.81^{* *}$ & $0.91^{* *}$ & $0.84^{* *}$ & $0.56^{*}$ \\
\hline M-1 & B & B & B & $\mathrm{C}$ & $\mathrm{C}$ & & $0.83^{* *}$ & $0.89^{* *}$ & $0.82^{* *}$ & $0.83^{* *}$ & $0.85^{* *}$ & $0.82^{* *}$ & $0.78^{* *}$ & $0.48^{* *}$ \\
\hline M-2 & B & B & $\mathrm{C}$ & $\mathrm{C}$ & $\mathrm{C}$ & B & & $0.86^{* *}$ & $0.80^{* *}$ & $0.82^{* *}$ & $0.84^{* *}$ & $0.87^{* *}$ & $0.83^{* *}$ & $0.47^{* *}$ \\
\hline M-3 & A & A & B & $\mathrm{C}$ & B & B & B & & $0.90^{* *}$ & $0.91^{* *}$ & $0.92^{* *}$ & $0.93^{* *}$ & $0.86^{* *}$ & $0.49^{* *}$ \\
\hline B-1 & A & A & B & $\mathrm{D}$ & B & B & B & A & & $0.98^{* *}$ & $0.95^{* *}$ & $0.90^{* *}$ & $0.84^{* *}$ & $0.38^{* *}$ \\
\hline B-2 & A & A & B & $\mathrm{D}$ & B & B & B & A & A & & $0.96^{* *}$ & $0.91^{* *}$ & $0.84^{* *}$ & $0.38^{* *}$ \\
\hline B-3 & A & A & B & $\mathrm{C}$ & B & B & B & A & A & A & & $0.92^{* *}$ & $0.85^{* *}$ & $0.37^{* *}$ \\
\hline B-4 & A & A & A & C & A & B & B & A & A & A & A & & $0.90^{*}$ & $0.50^{*}$ \\
\hline B-5 & B & B & B & B & B & C & B & B & B & B & B & A & & $0.48^{*}$ \\
\hline OS-1 & $\mathrm{F}$ & $\mathrm{F}$ & $\mathrm{F}$ & G & E & $\mathrm{F}$ & $\mathrm{F}$ & $\mathrm{F}$ & G & G & G & E & $\mathrm{F}$ & \\
\hline
\end{tabular}

p.s.: $p$ value: $*$ for $p=0.01 \sim 0.05 ; * *$ for $p=0.001 \sim 0.01$.

Correlation levels: A: $p$ > 90\%; B: 80 90\%; C: 70 79\%; D: 60 69\%; E: 50 59\%; F: 40 49\%; G: $p<39 \%$.

TABLE 6: $p$ value and quality for correlation coefficients for $\mathrm{O}_{3}$ concentrations measured by air quality monitoring stations for typhoon Usagi invading case.

\begin{tabular}{|c|c|c|c|c|c|c|c|c|c|c|c|c|c|c|}
\hline Station & O-1 & $\mathrm{O}-2$ & $\mathrm{O}-3$ & $\mathrm{O}-4$ & O-5 & M-1 & M-2 & M-3 & B-1 & B-2 & B-3 & B-4 & B-5 & OS-1 \\
\hline O-1 & & $0.97^{* *}$ & $0.91^{* *}$ & $0.82^{* *}$ & $0.92^{* *}$ & $0.81^{* *}$ & $0.83^{* *}$ & $0.84^{* *}$ & $0.92^{* *}$ & $0.94^{* *}$ & $0.93^{* *}$ & $0.91^{* *}$ & $0.87^{* *}$ & $0.37^{* *}$ \\
\hline $\mathrm{O}-2$ & A & & $0.91^{* *}$ & $0.82^{* *}$ & $0.92^{* *}$ & $0.79^{* *}$ & $0.82^{* *}$ & $0.84^{* *}$ & $0.89^{* *}$ & $0.91^{* *}$ & $0.91^{* *}$ & $0.92^{* *}$ & $0.87^{* *}$ & $0.38^{* *}$ \\
\hline O-3 & A & A & & $0.81^{* *}$ & $0.94^{* *}$ & $0.80^{* *}$ & $0.81^{* *}$ & $0.86^{* *}$ & $0.84^{* *}$ & $0.86^{* *}$ & $0.89^{* *}$ & $0.90^{* *}$ & $0.85^{* *}$ & $0.20^{*}$ \\
\hline $\mathrm{O}-4$ & B & B & B & & $0.89^{* *}$ & $0.76^{* *}$ & $0.88^{* *}$ & $0.82^{* *}$ & $0.80^{* *}$ & $0.84^{* *}$ & $0.85^{* *}$ & $0.88^{* *}$ & $0.88^{* *}$ & $0.25^{* *}$ \\
\hline O-5 & A & A & A & B & & $0.82^{* *}$ & $0.84^{* *}$ & $0.89^{* *}$ & $0.89^{* *}$ & $0.92^{* *}$ & $0.94^{* *}$ & $0.95^{* *}$ & $0.91^{* *}$ & $0.30^{* *}$ \\
\hline M-1 & B & $\mathrm{C}$ & B & $\mathrm{C}$ & B & & $0.82^{* *}$ & $0.87^{* *}$ & $0.83^{* *}$ & $0.83^{* *}$ & $0.80^{* *}$ & $0.76^{* *}$ & $0.81^{* *}$ & $0.18^{*}$ \\
\hline M-2 & B & B & B & B & B & B & & $0.93^{* *}$ & $0.84^{* *}$ & $0.83^{* *}$ & $0.86^{* *}$ & $0.90^{* *}$ & $0.82^{* *}$ & $0.18^{*}$ \\
\hline M-3 & B & B & B & B & B & B & A & & $0.84^{* *}$ & $0.86^{* *}$ & $0.86^{* *}$ & $0.88^{* *}$ & $0.89^{* *}$ & 0.16 \\
\hline B-1 & A & B & B & B & B & B & B & B & & $0.98^{* *}$ & $0.94^{* *}$ & $0.90^{* *}$ & $0.89^{* *}$ & $0.23^{*}$ \\
\hline B-2 & A & A & B & B & A & B & B & B & A & & $0.96^{* *}$ & $0.93^{* *}$ & $0.90^{* *}$ & $0.27^{* *}$ \\
\hline B-3 & A & A & B & B & A & B & B & B & A & A & & $0.95^{* *}$ & $0.90^{* *}$ & $0.30^{* *}$ \\
\hline B-4 & A & $\mathrm{A}$ & A & B & A & C & A & B & A & A & A & & $0.93^{*}$ & $0.30^{* *}$ \\
\hline B-5 & A & B & B & B & A & B & B & B & B & A & A & A & & $0.23^{*}$ \\
\hline OS-1 & G & G & G & G & G & G & G & G & G & G & G & G & G & \\
\hline
\end{tabular}

p.s.: $p$ value: $*$ for $p=0.01 \sim 0.05 ; * *$ for $p=0.001 \sim 0.01$.

Correlation levels: A: $p$ > 90\%; B: 80 90\%; C: 70 79\%; D: 60 69\%; E: 50 59\%; F: 40 49\%; G: $p<39 \%$.

in 2013 is 0.27 (excluding the insignificant relation between OS-1 and M-3). Therefore, the correlation coefficient in 2011 is higher than that in 2013, which shows the path method in 2011 has significant relation regarding the correlation with ozone concentration.

All of these results indicated that the air quality for these inland monitoring stations was dominantly affected by the same metrological conditions where leeside effects were strong. But, as shown in both Figures 6 and 10, the highest $\mathrm{O}_{3}$ concentration for the M-group station occurred a little bit earlier than the B-groups stations and O-group. It looks like an " $\mathrm{O}_{3}$ peak center" moves from east to west, just as the movement of both typhoons.
Furthermore, upon examining the variation pattern of the $\mathrm{O}_{3}$ concentration contours, the $\mathrm{O}_{3}$ concentration was found to follow the typhoon course. For instance, typhoon Nanmadol moved from southeast to northwest. The $\mathrm{O}_{3}$ concentration also faded in the same direction. Similarly, typhoon Usagi moved from east to west, and the $\mathrm{O}_{3}$ concentration faded in the same direction. Therefore, $\mathrm{O}_{3}$ spacefading patterns can be used as references to predict typhoon movement. Particularly, the $\mathrm{O}_{3}$ concentration variation patterns can be observed approximately 1.5 2.0 days before typhoons arrive. This indicates that this type of variation pattern of $\mathrm{O}_{3}$ concentration, including its concentration change and fading pattern, can be applied as references for 
predicting the moving tracks of typhoons approximately 1.5 2.0 days before typhoon really lands.

\section{Conclusion}

This study investigated the phenomena of forming highconcentrated $\mathrm{O}_{3}$ in the ambient air of southwestern Taiwan before arrival of both typhoons Nanmadol and Usagi which occurred in summer of 2011 and 2013, respectively. The relationships between tropical typhoon moving tracks and ambient air quality changes were modeled and analyzed with WRF-Chem. The results obtained in this study demonstrated the forming of high $\mathrm{O}_{3}$ concentration in the ambient air about 1.0 2.0 days before issuing sea warnings for both typhoons, which was about 2.0 3.0 days before real invading of typhoons. The approaching of typhoons caused the formation of atmospheric subsidence in southwestern Taiwan, resulting in $\mathrm{O}_{3}$ concentrations peaking as high as $140 \mathrm{ppb}$ which was 2 3 times higher than the normal concentration. The results also demonstrated that WPSH systems could deteriorate ambient air quality in summer, and the approaching of typhoons intensified the leeward side effects in the southwestern Taiwan to reduce vertical dispersion of air pollutants, causing high-concentration $\mathrm{O}_{3}$ forming in the ambient air. Finally, based on the simulated $\mathrm{O}_{3}$ concentration variation patterns, this study proposed that the space-fading patterns of $\mathrm{O}_{3}$ before typhoon arrives could be used as references for predicting typhoon moving tracks 2.0 to 3.0 days before typhoons really arrive.

\section{Conflict of Interests}

The authors declare that there is no conflict of interests regarding the publication of this paper.

\section{Acknowledgments}

The authors would like to thank both the Ministry of Science and Technology, Taiwan, and the National Kaohsiung First University of Science and Technology for financially supporting this research under Contract number: NSC 1022221-E-327-002-MY3 and A23200.

\section{References}

[1] A. Penrod, Y. Zhang, K. Wang, S.-Y. Wu, and L. R. Leung, "Impacts of future climate and emission changes on U.S. air quality," Atmospheric Environment, vol. 89, pp. 533-547, 2014.

[2] A. R. Ravishankara, J. P. Dawson, and D. A. Winner, "New directions: adapting air quality management to climate change: a must for planning," Atmospheric Environment, vol. 50, pp. 387389, 2012.

[3] R. Vautard and D. Hauglustaine, "Impact of global climate change on regional air quality: introduction to the thematic issue," Comptes Rendus Geoscience, vol. 339, no. 11-12, pp. 703708, 2007.

[4] N. Lin, P. Lane, K. A. Emanuel, R. M. Sullivan, and J. P. Donnelly, "Heightened hurricane surge risk in northwest Florida revealed from climatological-hydrodynamic modeling and paleorecord reconstruction," Journal of Geophysical Research D: Atmospheres, vol. 119, no. 14, pp. 8606-8623, 2014.

[5] J. P. Kossin, K. A. Emanuel, and G. A. Vecchi, "The poleward migration of the location of tropical cyclone maximum intensity," Nature, vol. 509, no. 7500, pp. 349-352, 2014.

[6] S.-H. Chiang and K.-T. Chang, "The potential impact of climate change on typhoon-triggered landslides in Taiwan, 2010-2099," Geomorphology, vol. 133, no. 3-4, pp. 143-151, 2011.

[7] G.-C. Fang, S.-J. Lin, S.-Y. Chang, and C.-C. K. Chou, "Effect of typhoon on atmospheric particulates in autumn in central Taiwan," Atmospheric Environment, vol. 43, no. 38, pp. 60396048, 2009.

[8] I.-F. Pun, I.-I. Lin, and D. S. Ko, "New generation of satellitederived ocean thermal structure for the western north pacific typhoon intensity forecasting," Progress in Oceanography, vol. 121, pp. 109-124, 2014.

[9] H.-J. Chu, C.-J. Liau, C.-H. Lin, and B.-S. Su, "Integration of fuzzy cluster analysis and kernel density estimation for tracking typhoon trajectories in the Taiwan region," Expert Systems with Applications, vol. 39, no. 10, pp. 9451-9457, 2012.

[10] M. R. Heal, C. Heaviside, R. M. Doherty, M. Vieno, D. S. Stevenson, and S. Vardoulakis, "Health burdens of surface ozone in the UK for a range of future scenarios," Environment International, vol. 61, pp. 36-44, 2013.

[11] H. H. Chang, H. Hao, and S. E. Sarnat, "A statistical modeling framework for projecting future ambient ozone and its health impact due to climate change," Atmospheric Environment, vol. 89, pp. 290-297, 2014.

[12] B. P. Singh, A. Kumar, D. Singh, M. Punia, K. Kumar, and V. K. Jain, "An assessment of ozone levels, UV radiation and their occupational health hazard estimation during photocopying operation," Journal of Hazardous Materials, vol. 275, pp. 55-62, 2014.

[13] K. Velchev, F. Cavalli, J. Hjorth et al., "Ozone over the Western Mediterranean Sea-results from two years of shipborne measurements," Atmospheric Chemistry and Physics, vol. 11, no. 2, pp. 675-688, 2011.

[14] M. M. Millán, E. Mantilla, R. Salvador et al., "Ozone cycles in the western Mediterranean basin: interpretation of monitoring data in complex coastal terrain," Journal of Applied Meteorology, vol. 39, no. 4, pp. 487-508, 2000.

[15] K. Vijayaraghavan, C. Lindhjem, A. DenBleyker et al., "Effects of light duty gasoline vehicle emission standards in the United States on ozone and particulate matter," Atmospheric Environment, vol. 60, pp. 109-120, 2012.

[16] Y.-P. Peng, K.-S. Chen, H.-K. Wang, C.-H. Lai, M.-H. Lin, and C.-H. Lee, "Applying model simulation and photochemical indicators to evaluate ozone sensitivity in southern Taiwan," Journal of Environmental Sciences, vol. 23, no. 5, pp. 790-797, 2011.

[17] P. Pai, K. Vijayaraghavan, and C. Seigneur, "Particulate matter modeling in the Los Angeles basin using SAQM-AERO," Journal of the Air \& Waste Management Association, vol. 50, no. 1, pp. 32-42, 2000.

[18] R. J. Yamartino, J. S. Scire, G. R. Carmichael, and Y. S. Chang, "The CALGRID mesoscale photochemical grid model-I. Model formulation," Atmospheric Environment Part A: General Topics, vol. 26, no. 8, pp. 1493-1512, 1992.

[19] J. Zheng, W. Che, Z. Zheng, L. Chen, and L. Zhong, "Analysis of spatial and temporal variability of PM10 concentrations using MODIS aerosol optical thickness in the pearl river delta region, 
China," Aerosol and Air Quality Research, vol. 13, no. 3, pp. 862876, 2013.

[20] G. A. Grell, J. Dudhia, and D. R. Stauffer, "A description of the fifth generation Penn State/NCAR mesoscale meteorology model (MM5)," NCAR Technical Note, 1994.

[21] S. E. Peckham, G. A. Grell, S. A. Mckeen et al., WRF/Chem Version 3.4 User's Guide. NOAA Earth System Research Laboratory, National Center for Atmosphere Research, Boulder, Colo, USA, 2012.

[22] R. Borge, V. Alexandrov, J. José del Vas, J. Lumbreras, and E. Rodríguez, "A comprehensive sensitivity analysis of the WRF model for air quality applications over the Iberian Peninsula," Atmospheric Environment, vol. 42, no. 37, pp. 8560-8574, 2008.

[23] H. Bian, X. Tie, J. Cao, Z. Ying, S. Han, and Y. Xue, "Analysis of a severe dust storm event over China: application of the WRFdust model," Aerosol and Air Quality Research, vol. 11, no. 4, pp. 419-428, 2011.

[24] F. Jiang, Q. Liu, X. Huang, T. Wang, B. Zhuang, and M. Xie, "Regional modeling of secondary organic aerosol over China using WRF/Chem," Journal of Aerosol Science, vol. 43, no. 1, pp. 57-73, 2012.

[25] G. Bagtasa, "Effect of synoptic scale weather disturbance to Philippine transboundary ozone pollution using WRF-Chem," International Journal of Environmental Science and Development, vol. 2, no. 5, pp. 402-405, 2011.

[26] F. Jiang, T. Wang, T. Wang, M. Xie, and H. Zhao, "Numerical modeling of a continuous photochemical pollution episode in Hong Kong using WRF-chem," Atmospheric Environment, vol. 42, no. 38, pp. 8717-8727, 2008.

[27] R. Kumar, M. Naja, G. G. Pfister, M. C. Barth, C. Wiedinmyer, and G. P. Brasseur, "Simulations over South Asia using the weather research and forecasting model with chemistry (WRFChem): chemistry evaluation and initial results," Geoscientific Model Development, vol. 5, no. 3, pp. 619-648, 2012.

[28] K.-C. Lo and C.-H. Hung, "The development and application of weather research forecast chemistry model," International Journal of Advancements in Computing Technology, vol. 4, no. 22, pp. 138-145, 2012.

[29] EPA Taiwan, Taiwan Emission Data System 8.1, Taiwan Environment Protection Administration, Taipei, Taiwan, 2013.

[30] J.-P. Huang, J. C. H. Fung, A. K. H. Lau, and Y. Qin, "Numerical simulation and process analysis of typhoon-related ozone episodes in Hong Kong," Journal of Geophysical Research D: Atmospheres, vol. 110, no. 5, Article ID D05301, 2005.

[31] K.-C. Lo and C.-H. Hung, "Forming high ozone concentration in the ambient air of Southern Taiwan under the effects of western pacific subtropical high," Advances in Meteorology, vol. 2015, Article ID 352630, 14 pages, 2015. 

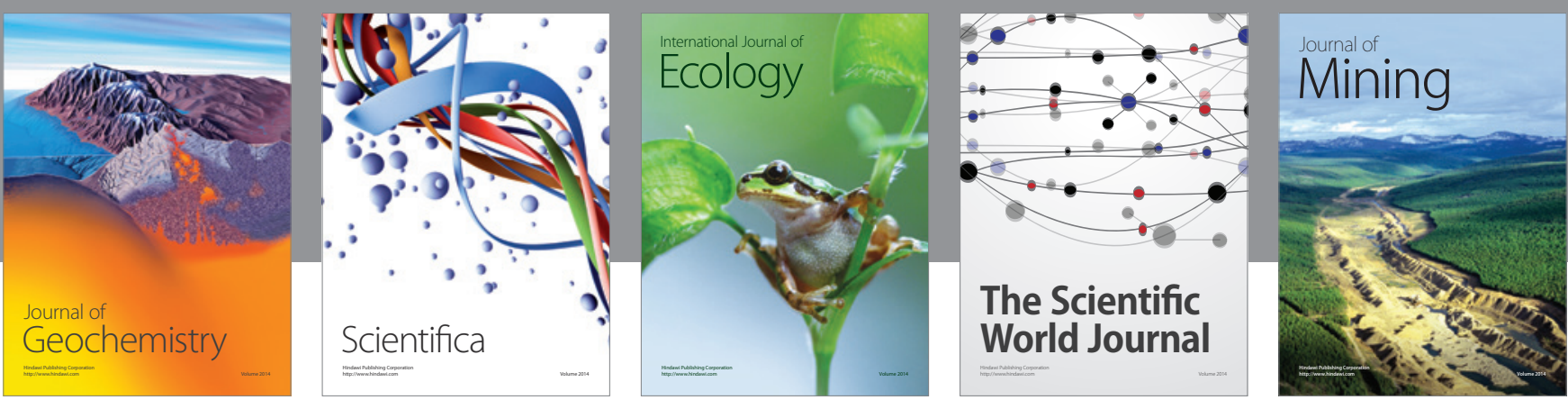

The Scientific World Journal
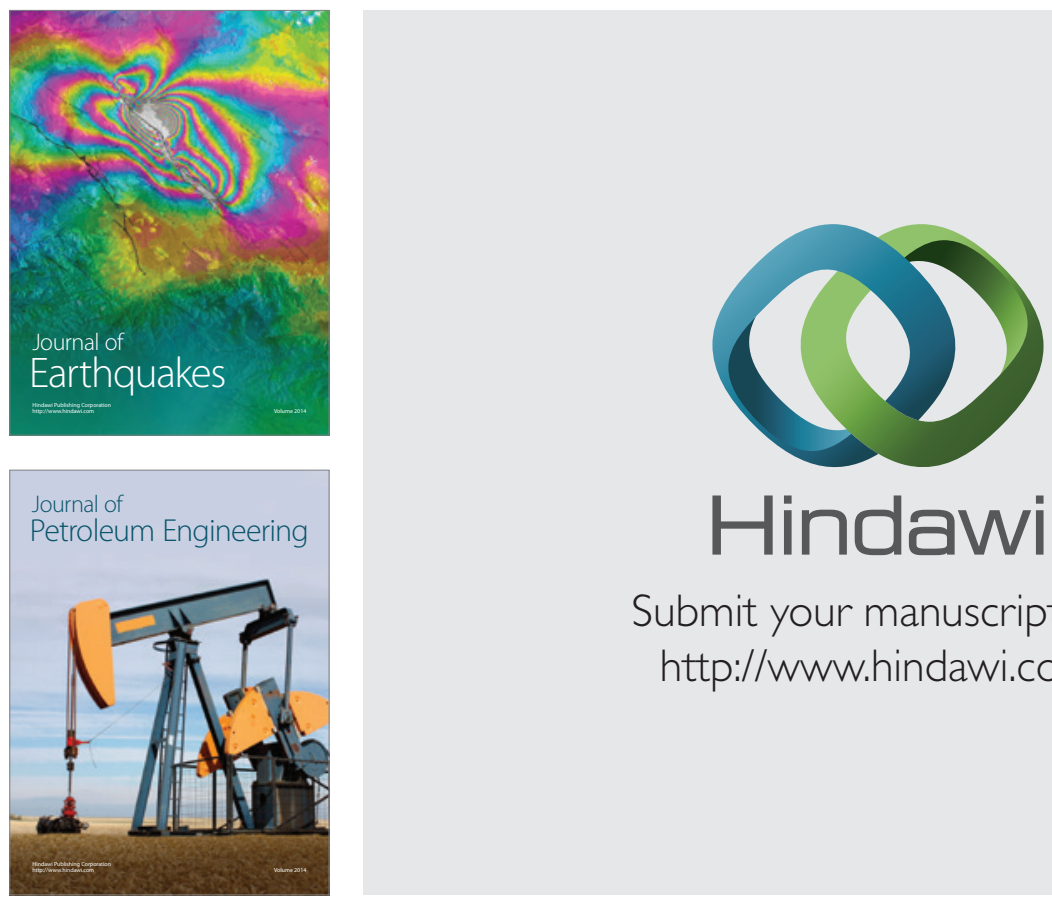

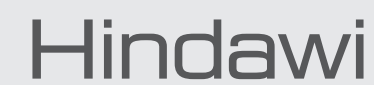

Submit your manuscripts at

http://www.hindawi.com
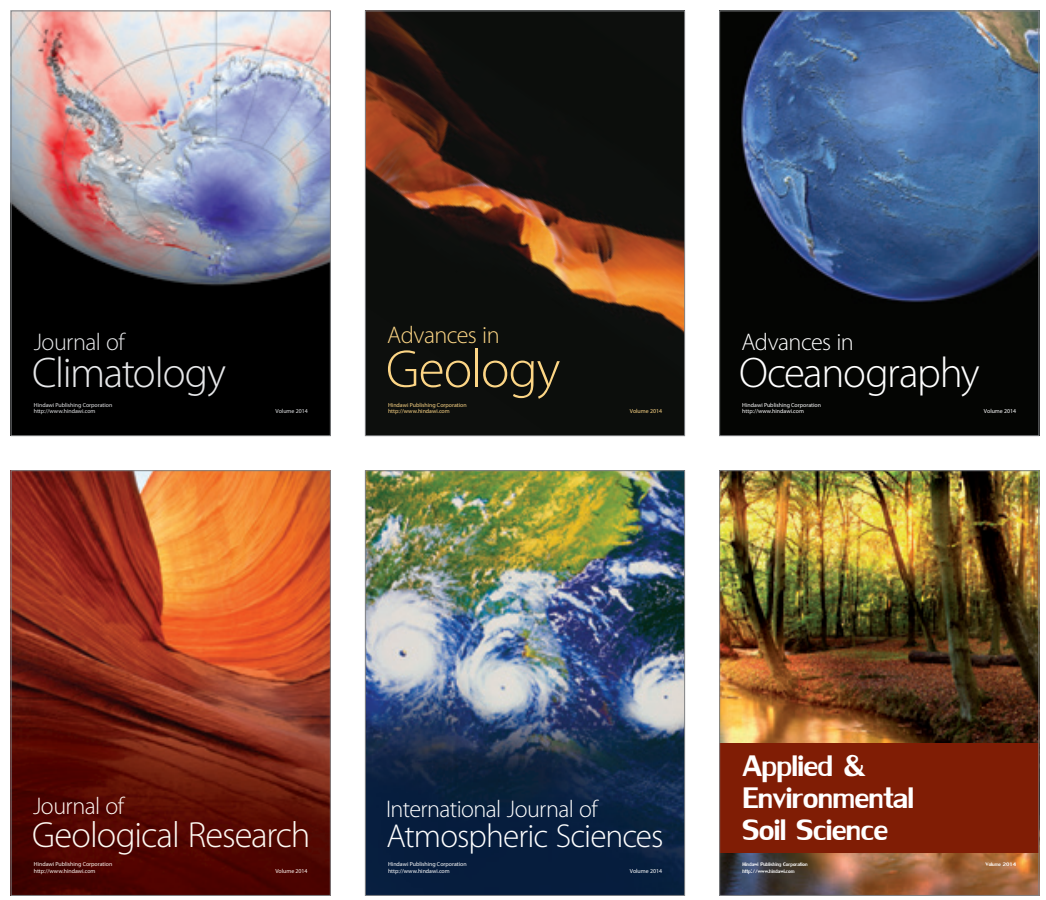
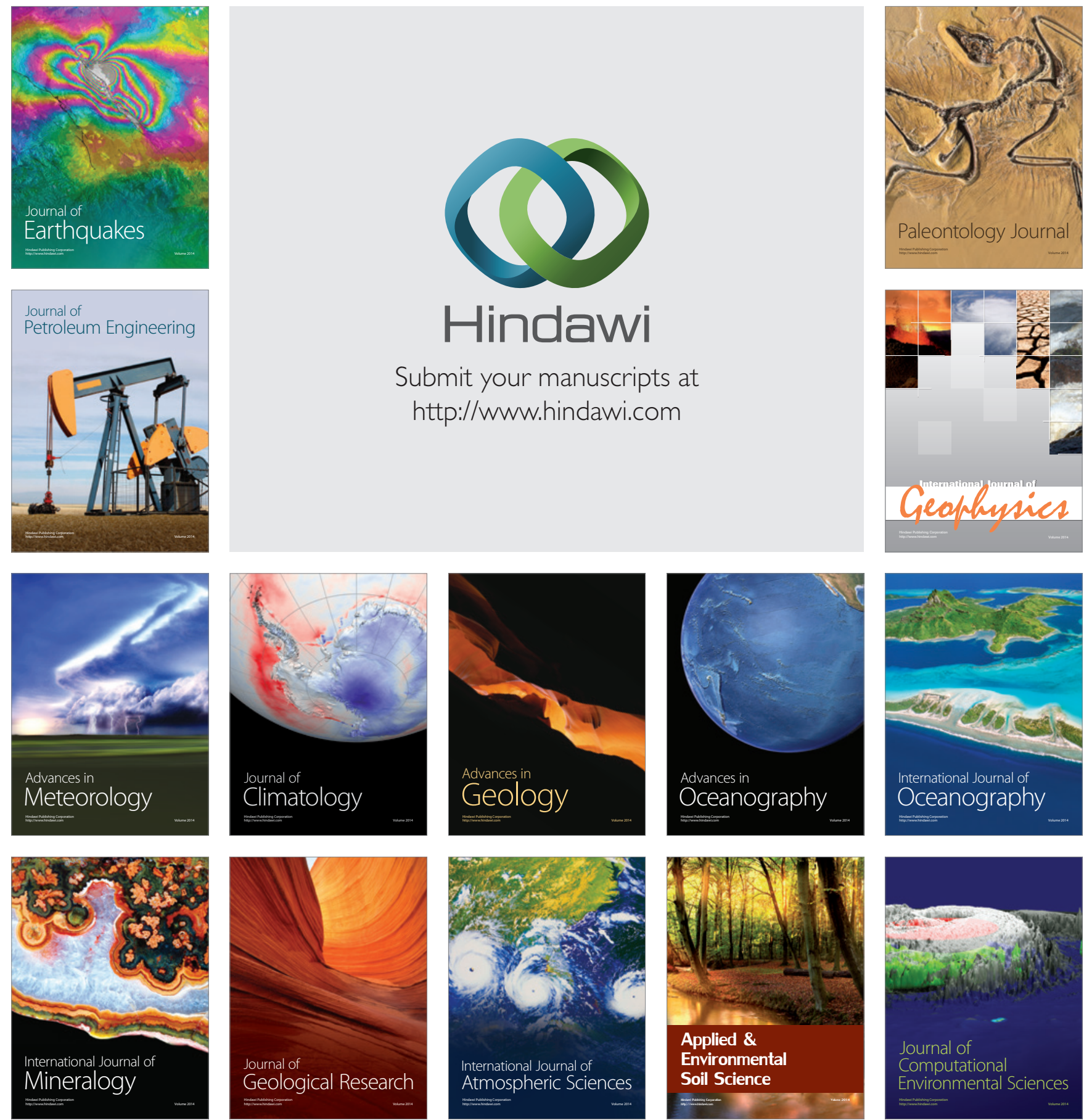